\title{
Central BANK BoARds AROUND THE World: WHY DOES MEMBERSHIP SIZE DIFFER?
}

\author{
HELGE BERGER \\ VOLKER NITSCH \\ TONNY LYBEK
}

\author{
CESIFO WORKING PAPER NO. 1897 \\ CATEgory 6: Monetary Policy and InTERnational FinanCe \\ JANUARY 2007
}

An electronic version of the paper may be downloaded

- from the SSRN website:

- from the RePEc website:

- from the CESifo website:

www.SSRN.com

www.RePEc.org

www.CESifo-group.de 


\title{
CENTRAL BANK BOARDS AROUND THE WORLD: WHY DOES MEMBERSHIP SIZE DIFFER?
}

\begin{abstract}
This paper analyzes empirically differences in the size of central bank boards across countries. Defining a board as the body that changes monetary instruments to achieve a specified target, we discuss the possible determinants of a board's size. The empirical relevance of these factors is examined using a new dataset that covers the de jure membership size of 84 central bank boards at the end of 2003. We find that larger and more heterogeneous countries, countries with stronger democratic institutions, countries with floating exchange rate regimes, and independent central banks with more staff tend to have larger boards.
\end{abstract}

JEL Code: E52, E58, E61.

Keywords: committee, council, governance, decision making, monetary policy.

\author{
Helge Berger \\ Free University Berlin \\ Department of Economics \\ Boltzmannstr. 20 \\ 14195 Berlin \\ Germany \\ hberger@wiwiss.fu-berlin.de
}

\author{
Volker Nitsch \\ Free University Berlin \\ Department of Economics \\ Boltzmannstr. 20 \\ 14195 Berlin \\ Germany \\ vnitsch@wiwiss.fu-berlin.de
}

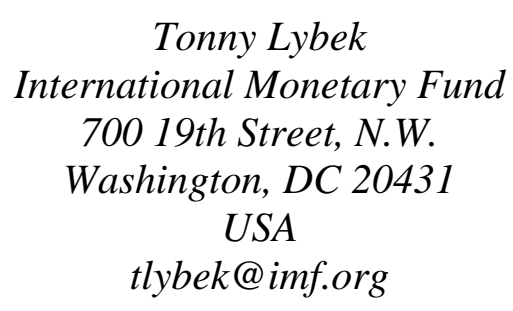

January 22, 2007

We thank the Deutsche Bundesbank, Martin Čihák, Robert Flood, Petra Gerlach, Jakob de Haan, Daniel Hardy, Chris Hunt, Alain Ize, Rodolfo Maino, Patricia Pollard, Steven Seelig, Pierre Siklos, Peter Stella, Jerome Vandenbussche, and seminar participants at the Bank of Canada, the IMF, and the Western Economic Association International meetings for helpful comments on previous drafts. Anne-Kristin Koch and Dominic Quint provided able research assistance. Berger and Nitsch thank the Fritz Thyssen Foundation for financial support. 


\section{INTRODUCTION}

Monetary policy may be a "science," but it is hardly an exact one. Given that policy decisions are surrounded by uncertainty, the way central banks exploit information and agree on decisions clearly matters for the quality and success of monetary policy. As a result, recent research has emphasized the importance of central bank organization — and in particular the size and structure of central bank boards or monetary policy committees (MPCs) - for monetary policy. ${ }^{1,2}$

The question of how many people should decide on monetary policy has recently also stirred interest on practical grounds. In Europe, the possible increase in euro area membership has triggered an intense debate on the optimal design of the decision-making process in the European Central Bank's (ECB's) 19-member Governing Council, in which there is at least one representative from each member country (see, for instance, Baldwin, Berglöf, Giavazzi, and Widgren, 2001; Berger, de Haan, and Inklaar, 2004). As an outcome of this discussion, the ECB has generally limited the (future) number of voting members to 21 . Even with this restriction, however, the Council appears to be relatively large compared with, for instance, the Bank of England's Monetary Policy Committee (9 members) or the Federal Reserve's Federal Open Market Committee (12). Of the

\footnotetext{
${ }^{1}$ To avoid confusion, we will hereinafter generally use the terms MPC or central bank board, instead of the various specific national terms describing the board, committee, council, or body in charge of deciding whether to change the monetary policy stance to achieve a specified target.

2 Other features of central bank design that may have the potential to affect the quality of monetary policy decision-making include the meeting procedures (consensus decisions, voting arrangements, etc. ), whether the members are full-time employees with the central bank or part-time external members, and if there are government representative(s), if any, with voting rights or the ability to temporarily postpone decisions. These factors, although important, are outside the scope of this paper.
} 
82 central banks surveyed by Fry, Julius, Mahadeva, Roger, and Sterne (2000), 55 institutions ( $\sim 67$ percent) had policy committees with 5-10 members.

In this paper, we aim to characterize differences in the membership size of decisionmaking bodies of central banks around the world. Since central banks often operate various boards, committees, and councils, we focus on the central bank's implementation board (or MPC) that makes decisions on whether and when to change policy instruments to achieve a given monetary policy target. Lybek and Morris (2004) provide a more detailed discussion of the various functions of central bank boards.

In principle, the optimal size of an MPC depends on the costs and benefits of membership size. ${ }^{3}$ The benefits from having more people on a board are mainly related to improvements in information processing. A larger number of board members should involve a broader range of experiences and perspectives and, hence, (ideally) be better in dealing with uncertainty — an argument that is loosely based on Condorcet's jury theorem. At the same time, decision making tends to become more difficult as board size increases. As membership size grows, different views are typically harder to reconcile, and discussions at board meetings often become more time consuming. As a result, decisions might be delayed or require more effort, thereby weakening the effectiveness of monetary policy.

\footnotetext{
${ }^{3}$ Our framework is related to the recent discussion on the size of boards of corporations. Reviewing the literature, Hermalin and Weisbach (2001, p. 31) note that: "Board composition [share of outside versus inside directors] is not related to corporate performance, while board size is negatively related to corporate performance. Both board composition and size do appear to be related to the quality of the board's decisions regarding CEO replacement, acquisitions, poison pills, and executive compensation." However, in the case of commercial corporations, the primary objective (e.g., to maximize shareholder wealth) is often clearer than for central banks. Furthermore, central bank boards typically have a smaller role, or none at all, in the appointment of the governor and in compensation decisions than commercial boards have.
} 
The exact structure of the trade-off between costs and benefits determining optimal MPC size, however, depends on country-specific characteristics. For instance, the argument to increase board size to achieve better information processing appears to be of particular relevance when an economy is large or characterized by considerable diversity across regions and industries. Similarly, a country's political institutions may matter for optimal MPC size. Less democratic regimes, for instance, may have a preference for a smaller board, since a larger MPC could provide useful insulation from political pressures. ${ }^{4,5}$ Finally, MPC size is probably also affected by other elements of central bank design such as the institutional functions performed by a central bank. If the central bank enjoys full autonomy over both policy targets and instruments, the MPC may be larger than when the central bank's autonomy is more limited. In view of the considerable cross-country variation along economic, political, and institutional dimensions, Goodfriend (2005, p. 85) argues that "the efficient size of a policy committee might vary across countries."6

In the following sections, we analyze empirically whether country-specific features help to explain differences in MPC size. Our results indicate that board size is indeed strongly and plausibly associated with a number of country-specific characteristics. We find,

\footnotetext{
${ }^{4}$ One argument could be that large board size combined with anonymous majority voting would allow individual board members to claim to have been outvoted or otherwise dominated in the decision-making process.

${ }^{5}$ Related to size, it may in practice also make a difference if some of the MPC members are full-time employees of the central bank (i.e., "internal members") whose future careers may depend on the chairman of the MPC, typically the governor, or the members are "external" members. In the case of the former, the meeting dynamics may also be influenced by Keynes's "beauty contest factor," where these members may also be tempted to refine their own interventions in line with those they expect the chairman will favor. The special role of the chairman (see, for instance, Chappell, McGregor, and Vermilyea 2004) and the issue of internal and external members (see, for example, Tuladhar 2005, who provides such information on MPCs in inflationtargeting countries) are indeed important, but lie outside the scope of this paper.
} 
for instance, that board size is positively related to country size, thereby providing strong support for the theoretical and experimental observation that a central bank's informationprocessing requirements affect board size. We also find that MPC size is related to a country's political institutions, with more democratic countries having, on average, larger boards. Finally, MPC size is often associated with other central bank characteristics. Central banks that have a more complex monetary strategy, a longer history, and more staff typically have more board members who serve, on average, shorter terms.

The remainder of the paper is organized as follows. In Section II, we provide a detailed discussion of possible determinants of MPC size. Section III presents the data and the empirical results, and Section IV provides a brief conclusion.

\section{Possible Determinants of Central Bank Board Size}

The size of the central bank board, or the MPC, is an important feature of central bank design. In practice, the decision on the number of board members appears to reflect various factors, including the political environment in which the decision on MPC size is made. In fact, one way to picture the decision process on board size is purely political. For instance, the number of central bank board members could be the result of a bargaining process that involves different interest groups (e.g., the financial sector, trade unions, or export industries) aiming at direct or indirect representation in the MPC. ${ }^{7}$ Alternatively, the decision on MPC size could take the form of a conscious design decision of a decision-maker

\footnotetext{
${ }^{6}$ Sibert (2006, p. 1) notes, in similar fashion, that, "[a]s a result of shirking and coordination problems, smaller committees may be better than larger ones and the optimal size for a committee is an empirical issue."
} 
based on social or private preferences and subject to more or less binding political

constraints. $^{8}$ Following the more recent literature, however, we will organize our discussion of the determinants of central bank board size around the trade-off of (some of the more obvious) costs and benefits of an increasing number of board members. ${ }^{9}$

\section{A. The Basic Trade-Off}

On the benefit side, the most prominent argument in favor of increasing the number of MPC members is that larger MPCs could be in a better position to process, analyze, and interpret economic information—ultimately leading to better monetary policy decisionsthan individuals relying mostly on their own information and judgment. Working in a notoriously uncertain macroeconomic environment, multiple MPC members are able to pool information and exploit divisions of labor in information processing. ${ }^{10}$ The argument has been formalized, among others, by Gerlach-Kristen (2006) and Berk and Bierut (2004); supportive experimental evidence is produced by Blinder and Morgan (2005) and

\footnotetext{
${ }^{7}$ A case in point are the recent amendments to the central bank law of Hungary in 2004, where the balance in the monetary policy committee was changed by increasing the number of members.

${ }^{8}$ Provided the central bank independence paradigm is acknowledged, the design-scenario may be more relevant for boards that primarily make decisions on whether to change monetary policy instruments to achieve a specified target (instrument autonomy) than for policy boards that are also involved in determining the target of the central bank (target autonomy) or even deciding on its primary objective (goal autonomy), which is much more normative.

${ }^{9}$ See, among others, Goodfriend (2005), Berger (2006), and Sibert (2006). It should be noted that the forces shaping any political process relevant for the decision on MPC size may be somewhat similar in nature to the forces considered in a cost-benefit approach.

${ }^{10}$ MPC members may contribute by their differences in various ways, namely by the: (i) underlying model, meaning the underlying paradigms in which they believe; (ii) their experiences, meaning how they "estimate" the parameters in their model; (iii) the information set they use as input in their model; and not least (iv) different objective functions, which explicitly or implicitly may differ from the primary objective of the MPC.
} 
Lombardelli, Proudman, and Talbot (2005). ${ }^{11}$ Gerling, Grüner, Kiel, and Schulte (2005) and Fujiki (2005) provide comprehensive surveys of the literature; Sibert (2006) and Vandenbussche (2006) review the related — and highly useful—social psychology literature that looks at the effects of group size on information processing and moderation. ${ }^{12}$

On the cost side, a plausible conjecture is that larger MPCs will generally imply greater effort from all involved for a given decision problem which may translate into less effective monetary policy making. The most important aspect is communication among members (and the resulting dynamics of the discussion). For instance, it seems obvious that even if the exchange of ideas at the preparatory stage of a decision is limited to a solitary statement by MPC members addressing their colleagues, larger MPCs would require more time than smaller MPCs in reaching a decision. Moreover, actual decision-making costs are likely to have a non-linear component. If MPC members regularly "sound each other out" during meetings (see, for instance, Barber 2001), the time requirement for preparing a decision will rise exponentially in the number of members (Berger 2006). ${ }^{13}$ Moreover, individual representation at the board becomes less important as the number of decision

\footnotetext{
${ }^{11}$ Already Blinder (1998) noted that in a committee decisions tend to regress toward the mean, making it very difficult for idiosyncratic (or extreme) views to prevail. More recent contributions pointing in the same direction include Riboni and Ruge-Murcia (2006). Méon (2006, p. 1), for instance, shows that: "The volatility of the policy is smaller the smaller the volatility of members' preferences, smaller the larger the size of the committee, and smaller than if it was chosen by a single member." Sibert (2006), however, argues that decision-making by committee may not necessarily result in moderation.

${ }^{12}$ Schein (1999) is a related contribution from the business literature that looks at group-based decision making.

${ }^{13}$ If there are $n$ MPC members, the number of bilateral discussions is $1 / 2\left(n^{2}-n\right)$. The need for preparatory communication will be especially pronounced in central bank environments given to consensus-based decision making. This includes roughly half of the more than 80 central banks surveyed by Fry et al. (2000).
} 
makers increases so that the gains from diversity of skills and perspectives of members become smaller for larger central bank boards. ${ }^{14}$

The view that increasing MPC membership size may reduce the effectiveness of policy-making is also bolstered by real-world experience. The German Bundesbank, for instance, asserts that its 1992 MPC reform triggered by German unification helped to prevent an increase in MPC size which "would have greatly complicated that body's decision-making processes" (Deutsche Bundesbank 1992, p. 50). More recently, the ECB (2003, p. 83) has expressed the fear that the anticipated increase in the number of national central bank governors attending euro area MPC meetings after EMU enlargement "will not necessarily make deliberations easier".

The trade-off between costs and benefits determining optimal MPC size is influenced by a number of country characteristics. As Goodfriend (2005) argues, larger and more heterogeneous currency areas may benefit particularly from larger MPCs. This could be because of increased monitoring necessities or because a higher level of economic development gives rise to more complex monetary strategies, which may require larger decision-making bodies. Moreover, "[i]f an economy is complex, even if not particularly large geographically, then it might be useful to have the views of the key sectors represented on the policy committee" (p.85). At the same time, the costs of larger MPCs are also likely to vary with the size of the economy. For instance, the size of MPCs is less relevant for (the costs of) decision-making in cases where the central bank runs monetary policy for a small,

\footnotetext{
14 Blinder and Morgan (2005) argue that small but not-too-large-groups of individuals may reach "better" decisions at speeds broadly comparable to an individual. As groups increase, however, individual members may have a stronger incentive to "freeride" on the information processing efforts of others, especially if information processing is a costly activity, which will lead to growing inefficiencies (e.g., Sibert 2006).
} 
open, and highly integrated economy so that there is a priori little room for independent policy-making in the first place. Similarly, decision-making costs may vary with the underlying cultural consensus or democratic structure, which, in turn, could be a function of country size or heterogeneity. ${ }^{15}$

\section{B. Determinants of Monetary Policy Committee Size}

In what follows, we present a number of relevant and empirically testable hypotheses along this line, aiming to make the argument for an association between MPC size and country characteristics operational.

\section{Country size and heterogeneity}

As a starting point, it seems safe to assume that a central bank's requirements for information processing are a (positive) function of (within-)country diversity and country size. For instance, for economies with complex structures, a large number of central bank board members might be particularly useful, allowing a review in detail of the (often diverse) information from various sectors and regions. Also, it is often larger currency areas that host a more heterogeneous population with diverging preferences and/or varying institutional and cultural backgrounds, possibly weighing on monetary policy. ${ }^{16}$ For instance, if larger

\footnotetext{
${ }^{15}$ For instance, costs could be influenced by the nature of the decision-making process, such as the prevalence of consensus-based traditions, majority voting, or leadership style of the MPC's president. "Group think," the risk that one or a few charismatic persons dominate and prevent valid critical questions be addressed, may be less problematic in larger boards. A more detailed discussion can be found in Berger (2006).

${ }^{16}$ Of course, there are also political-economic factors that could translate heterogeneity into larger MPC size. For instance, in the absence of proper democratic institutions, a more politically diverse population might require a larger MPC to represent all relevant interest groups, possibly including external members. We return to this issue below.
} 
countries tend to produce more federal political structures, these structures may more easily translate into the presence of regional representatives in the MPC. ${ }^{17}$ Finally, larger countries may be more independent in their monetary policy, which may make having larger MPCs more worthwhile. In sum, we hypothesize that measures of country size such as land area or population are positively correlated with MPC size. Similarly, measures of a country's cultural or political fragmentation may have a positive influence on the size of the MPC.

\section{Development and openness}

Another group of empirically identifiable factors that potentially affect MPC size are the economy's state of economic development and its degree of external openness. One plausible conjecture that links central bank organization to the level of economic development is that the existence of a more elaborate monetary policy framework, including perhaps a larger MPC, may be a positive function of the average income level in a country. More specifically, larger and more developed economies could be less inclined to opt for simple monetary rules (such as a fixed exchange rate) and introduce more complex strategies (such as forward-looking inflation targeting), which may require larger MPCs to manage. ${ }^{18}$ Also, countries at higher income levels and with more developed financial markets should have a larger supply of well-educated staff and (well-qualified) potential MPC members, thereby loosen any possible constraint imposed on MPC size at lower income levels. Furthermore,

\footnotetext{
17 On regional representation in MPCs, see, among others, Berger and de Haan (2002), Meade and Sheets (2005), and Berger (2006).

18 Another link pointing in that direction is that more financial development means that more people depend on financial assets and hence are more vulnerable to inflation (Posen, 1995). As they demand more central bank autonomy and accountability, this could imply the establishment of larger central bank boards. In less
}

(continued...) 
more developed and dynamic financial markets may result in more frequent changes in the monetary transmission mechanism which implies the need for more balanced information when adjusting the monetary policy instruments.

On openness, Romer (1993) has argued that economies more open to international trade are more sensitive to currency fluctuations and this sensitivity should lead to a more disciplined economic policy overall. If openness is indeed making the MPC's life easier, by imposing, for instance, greater discipline on fiscal policy, a fewer number of board numbers are needed in more open economies. The same should hold, other things equal, for economies characterized by a high correlation of the national business cycle with the world cycle. $^{19}$

\section{Political institutions}

A larger MPC may also have advantages for political economy reasons. As noted before, diversity in terms of language or culture may increase the attractiveness of a larger MPC which would allow fuller representation of varying interests and thereby increase the likelihood of gaining political legitimacy. Along similar lines, it could be argued that more developed democratic institutions allow for greater diversity in opinion and preferences and, therefore, may be a factor in favor of a more sizable MPC.

\footnotetext{
developed countries, which typically have a younger population, the preference toward price stability may be smaller.

${ }^{19}$ Empirically, a high degree of openness at period $t$ may or may not be highly correlated with measures of business cycle correlation in the past. D'Amato and Martina (2005) argue on theoretical grounds that a high degree of business cycle correlation across countries should provide incentives to decrease central bank independence. If this was correct, and larger MPCs and central bank independence were substitutes (see below), this would lead us to expect a positive correlation between a correlation measure and MPC size.
} 
Another potentially relevant argument from a political economy perspective is related to the incentive of governments to dominate monetary policy for fiscal reasons. At the extreme, this may lead to fiscal determinacy of the price level, where monetary policy is forced to fully accommodate excessive fiscal behavior, including financing quasi-fiscal activities, and to allow runaway inflation to deflate the level of public debt (see, e.g., Woodford 2003). At a less drastic level, government officials may put pressure on the MPC to ease monetary policy and thereby lower the interest burden for the public finances. To insulate monetary policy from these pressures, optimal central bank design would aim for a high degree of central bank independence (see, e.g., Rogoff 1985), which may include establishing a large MPC (since larger boards may be less easily swayed by government influence).$^{20}$ As a consequence, we might observe a positive correlation between MPC size and measures of fiscal pressure. Similarly, under the assumption that such pressures are present, MPC size may be complemented by stricter limits on central bank financing of fiscal deficits. $^{21}$

\section{Other central bank characteristics}

Finally, if the membership size of the central bank board is part of a multidimensional design process of central bank organization, we may expect that other design choices are

\footnotetext{
${ }^{20}$ Blinder (2006, p. 3) argues that, "[w] hen the central bank was just following orders communicated by the government, there was not much reason to have a committee on the other end of the phone. An individual governor sufficed-and also limited the phone bill."

${ }^{21}$ Strictly speaking, the latter argument is an element of central bank design rather than the political environment (see following section). In practice, deficit financing is increasingly being alleviated by central bank legislation explicitly prohibiting direct or indirect central bank financing of the fiscal deficits and the financing of quasi-fiscal activities.
} 
reflected in MPC size as well. For instance, with reference to the discussion above, if central banks have greater autonomy (e.g., the authority to prioritize their objectives and specify the target to pursue generally), they are likely to have larger MPCs. More generally, central banks that are more independent from government are expected to operate under larger MPCs.

In similar fashion, the monetary policy strategy and the exchange rate regime in which a central bank operates may be relevant determinants of MPC size. Decisions on changing interest rates require less deliberation and forward-looking analysis, and thus a smaller MPC, under a fixed exchange rate regime (where the central bank essentially follows the monetary policy of the anchor country) than monetary policy under floating exchange rates.

In addition, one may argue that there is a negative association between MPC size and the (envisaged) average term length of MPC members since smaller groups require longer terms to ensure continuity. ${ }^{22}$ Alternatively, larger groups are able to accommodate higher fluctuation frequencies without endangering the independence of the MPC from the government (which is likely to be involved in the nomination of new members). ${ }^{23}$

Another factor that might be associated with MPC size is the number of central bank staff. A possible link between the two variables is number of functions performed by the central bank, which may require both more staff and a larger MPC (e.g., if the MPC has also

\footnotetext{
22 Another possible link could be the so-called stabilization bias of monetary policy (e.g., Woodford 2003): if larger groups mean slower decision-making, larger MPCs could be a means to introduce optimal inertia into interest rate setting - albeit perhaps not an efficient one. See Mirzoev (2004) for an argument for lowering the meeting frequency of MPCs to achieve the same effect.

23 A related literature discusses central bank appointments and staggered contracts; see, for instance, Waller $(1989,1992,2002)$ and Waller and Walsh (1996).
} 
duties other than to decide on monetary policy). ${ }^{24}$ The central bank's operating expenditures may be another proxy for the functions performed by the central bank. Finally, path dependencies (possibly captured by the age of the institution) may play a role for MPC size, with younger institutions being plausibly characterized by (yet) smaller boards.

\section{EMPIRICAL ANALYSIS}

In the following, we test the above predictions empirically. Our strategy is to examine the association between MPC size and country characteristics in a very general fashion. Instead of emphasizing a particular variable or estimation method, we use a (large) number of alternative measures and a variety of simple econometric specifications to identify possible structural correlations in the data. This approach also helps to take account of possible data limitations for individual variables. We begin this section by describing our data, and then turn to testing the relationships between MPC size and various country characteristics, including features of central bank design.

\section{A. Data Description}

At the heart of our data set is the MPC size data obtained from Lybek and Morris (2004). This publication surveys 101 central bank laws (covering 113 countries) at the end of 2003 and classifies the governance structure of central banks along various dimensions. Lybek and Morris (2004) distinguish between different types of central bank boards (policy

\footnotetext{
${ }^{24}$ Alternatively, there could be specialized "boards" to deal with other functions. The Reserve Bank of Australia is a case in point having a special Payment System Board.
} 
boards, implementation boards, pure supervisory boards, and advisory bodies) depending on the type of autonomy. We use information on the most relevant and powerful central bank board, the "implementation board," i.e., the body that decides whether to change monetary policy instruments to achieve a specified target. Since Lybek and Morris (2004) have grouped MPCs into size classes of three members, we use effectively a board size index that takes the value of one if the MPC consists of 1-3 members, the value of two if there are 4-6 members, and so on. ${ }^{25}$ Figure 1 provides a histogram of our MPC size measure. The 84 countries included in our sample are listed in Appendix I. ${ }^{26}$

Our accompanying data on country characteristics and central bank features come from a number of different sources. Most of the data on country characteristics are taken from Rose (2006), who has compiled a large and comprehensive data set of country attributes, including physical, cultural, economic, political, geographic, and social phenomena. To this data set, we add information on various central bank features such as the term length of board members, the type of legal independence, the establishment year, staff size, and operational expenses of the central bank. This information is mainly obtained from Lybek and Morris (2004); other sources are the Morgan Stanley Central Bank Directory, Fry et al. (2000), and Ize (2006). Finally, we have compiled macroeconomic data (e.g., on a country's fiscal position) from the International Monetary Fund's International Financial

\footnotetext{
${ }^{25}$ Lybek and Morris (2004) provide no information on the precise number of MPC members. It should be noted, however, that also some central bank laws stipulate no fixed number but give a range for the number of required board members. Another qualification of the Lybek and Morris data is that they focus on boards and committees and therefore provide no information on central banks where the governor alone is responsible for decisions on how to implement the policy. Thus, de facto our smallest size category for board membership covers boards with $2-3$ members.
} 
Figure 1. Histogram of Board Size

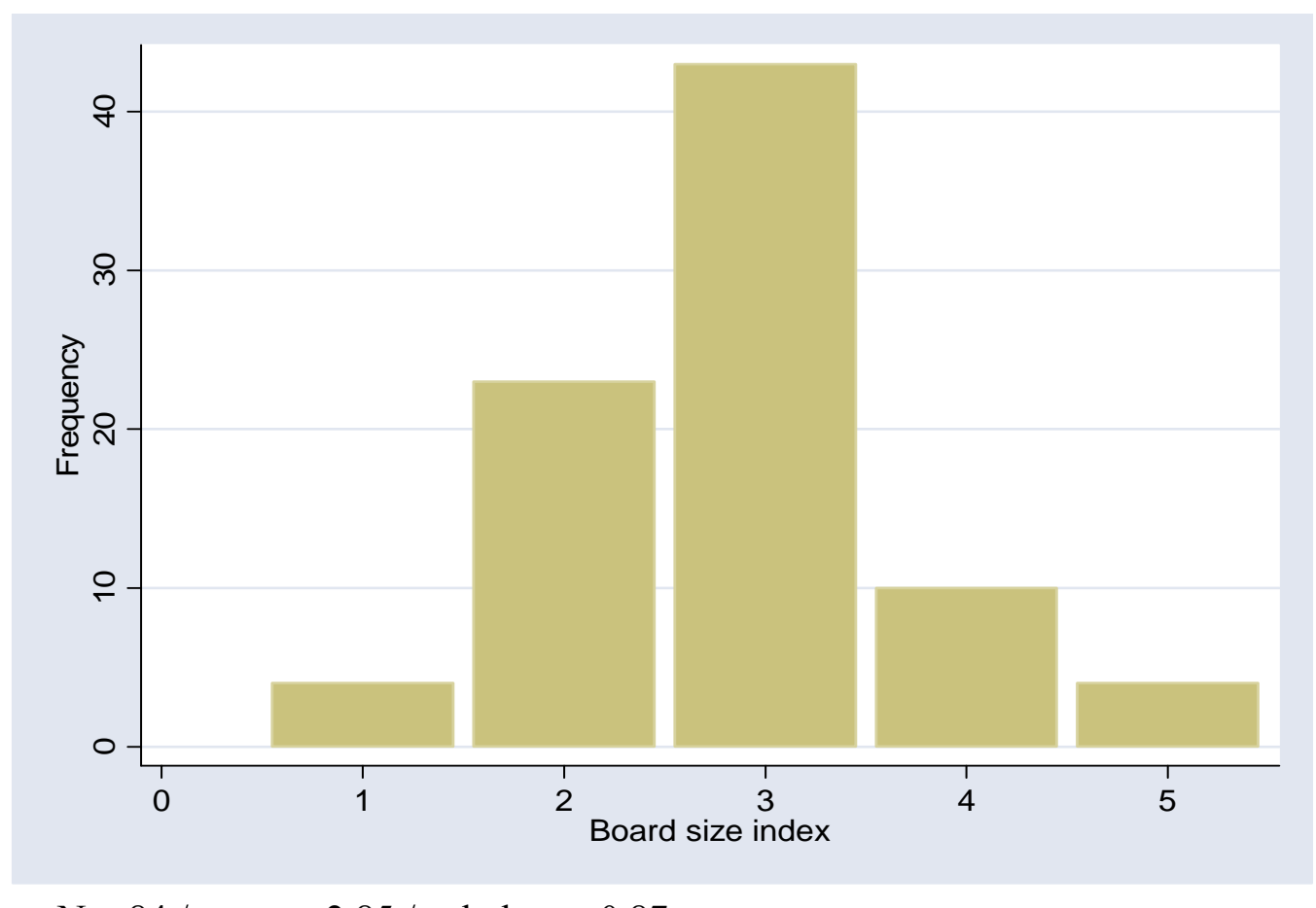

$\mathrm{N}=84 /$ mean $=2.85 /$ std. dev. $=0.87$

${ }^{26}$ The main difference to the Lybek and Morris (2004) sample of 101 central bank laws is that we drop central banks that are involved in a multilateral currency union (since these central banks have either no responsibility for monetary policy or make decisions on monetary policy for a larger currency area). 
Statistics. We also use three different exchange rate regime classifications: the well-known de facto classifications from Levy-Yeyati and Sturzenegger (2005) and Reinhart and Rogoff (2004), and the de jure classification from the IMF (2003). Detailed sources for variables are tabulated in Appendix II. Appendix III provides descriptive statistics. ${ }^{27}$

\section{B. Methodology}

We now turn to the correlates of central bank board size. We estimate both simple bivariate models and models augmented with a few key controls. In particular, we estimate regressions of the form:

$$
M P C=\alpha+\beta x+\gamma Y+\varepsilon
$$

where MPC is our ordered MPC (or board) size index, $x$ is the variable of interest, $Y$ is a set of control variables and $\varepsilon$ is a well-behaved residual. Due to the discrete categorical nature of our dependent variable, we estimate our equation using ordered probit techniques.

\footnotetext{
${ }^{27}$ Most explanatory variables are either time-invariant or contemporaneous to MPC size. The underlying hypothesis is that the size of MPCs (as any element of central bank design) is subject to constant re-evaluation, either through the relevant authorities or the underlying political process. If this is indeed the case, we expect our explanatory variables to show a significant impact on MPC size. The alternative hypothesis is that MPC size is determined in a "one shot" game or design decision and not subject to change. In this case, finding a significant relationship with current country characteristics would be less likely, at least if the determinants of MPC size change over time. In practice, however, with many of the explanatory variables showing considerable inertia themselves (and the recent wave of central bank reforms having changed MPC sizes in a number of countries including, for instance, the U.K. and Sweden), the distinction between both views is somewhat less sharp than what one might think. Ultimately, however, this is an empirical question.
} 
Table 1. Characterizing MPCs: Size

\begin{tabular}{|l|l|l|l|l|}
\hline & Obs. & $\begin{array}{l}\text { Bivariate } \\
\text { ordered } \\
\text { probit }\end{array}$ & $\begin{array}{l}\text { Augmented } \\
\text { ordered } \\
\text { probit }\end{array}$ & $\begin{array}{l}\text { Probit with } \\
\text { binary dep. } \\
\text { variable }\end{array}$ \\
\hline Population & 84 & $\begin{array}{l}0.009^{* *} \\
(0.002)\end{array}$ & $\begin{array}{l}0.010^{* *} \\
(0.002)\end{array}$ & $0.02^{*}$ \\
$(0.01)$
\end{tabular}

Note: Standard errors are in parentheses. **,* and \# denote significant at the $0.01,0.05$ and 0.10 level, respectively.

Table 2. Characterizing MPCs: Heterogeneity

\begin{tabular}{|l|l|l|l|l|}
\hline & Obs. & $\begin{array}{l}\text { Bivariate } \\
\text { ordered } \\
\text { probit }\end{array}$ & $\begin{array}{l}\text { Augmented } \\
\text { ordered } \\
\text { probit }\end{array}$ & $\begin{array}{l}\text { Probit with } \\
\text { binary dep. } \\
\text { variable }\end{array}$ \\
\hline Ethnolinguistic Fractionalization & 50 & $\begin{array}{l}1.12 * \\
(0.55)\end{array}$ & $\begin{array}{c}1.04 \# \\
(0.61)\end{array}$ & $\begin{array}{c}0.97 \\
(0.67)\end{array}$ \\
\hline Ethnic Fractionalization, CH & 64 & $0.009 \#$ & 0.007 & 0.007 \\
& & $(0.005)$ & $(0.006)$ & $(0.006)$ \\
\hline Ethnic Fractionalization, & 38 & 0.19 & -0.40 & 0.77 \\
ADEKW & & $(0.72)$ & $(0.89)$ & $(0.93)$ \\
\hline Linguistic Diversity & 84 & 0.21 & 0.21 & 0.48 \\
& & $(0.39)$ & $(0.40)$ & $(0.49)$ \\
\hline Linguistic Fractionalization & 80 & -0.04 & -0.21 & -0.08 \\
& & $(0.44)$ & $(0.50)$ & $(0.55)$ \\
\hline Religious Fractionalization & 83 & 0.75 & 0.65 & 0.90 \\
& & $(0.53)$ & $(0.55)$ & $(0.63)$ \\
\hline Gini Coefficient & 62 & -0.003 & -0.01 & -0.02 \\
& & $(0.012)$ & $(0.01)$ & $(0.02)$ \\
\hline Geographic Dispersion & 59 & 0.07 & 0.04 & -0.55 \\
& & $(0.74)$ & $(0.70)$ & $(0.91)$ \\
\hline Administrative Divisions & 83 & $0.006 \#$ & 0.002 & $0.02 *$ \\
& & $(0.003)$ & $(0.002)$ & $(0.01)$ \\
\hline
\end{tabular}

Note: Standard errors are in parentheses. **,* and \# denote significant at the $0.01,0.05$ and 0.10 level, respectively. 


\section{Bivariate Results}

Tables $1-5$ present the benchmark estimation results. For each variable, we report three sets of estimates. The first column records the slope coefficients obtained from simple bivariate estimation. ${ }^{28}$ In column 2 , we report the results of an augmented regression, in which population and per capita income are added as control variables. ${ }^{29}$ Finally, the last column presents the bivarate results with the MPC size measure transformed into a binary index that takes the value of one if the MPC comprises more than six members and zero otherwise; these results are based on standard probit estimates. In practice, it turns out that all of our key findings are robust to this transformation of board size into small and large boards; this also suggests that our results are not sensitive to outliers. ${ }^{30}$ In the following, we group variables along the lines of arguments outlined in the previous section.

Table 1 examines the linkage between (various indicators of) country size and MPC size. Most of the estimated coefficients are positive and statistically significant, suggesting that larger countries tend to have larger central bank boards. Reviewing the results in detail, the measure that is most closely related to Condorcet's jury theorem is a country's total population. The estimated coefficient on this variable is strongly positive (across all specifications) and statistically highly significant, indicating that more populous countries have more MPC members. For other useful proxies of country size, such as land area (as a

\footnotetext{
28 Appendix IV shows accompanying scatter plots (for most variables).

${ }^{29}$ We have also experimented with other sets of controls (e.g., central bank staff). The main findings were basically unaffected.
} 
measure of a country's physical extension) or the gross domestic product (as a proxy for economic mass), the results are basically identical (which is not totally surprising given the generally strong positive correlation between these measures).

There is also some evidence that heterogeneity is associated with larger central bank boards (Table 2). As argued in Section II, greater diversity provides good reason for the creation of larger MPCs. This reasoning, however, may be more relevant for policy boards than for more technical boards such as MPCs that determine whether to change interest rates to achieve a specified target. To explore this issue empirically, we examine a broad range of variables on population heterogeneity, including various measures of ethnic, linguistic, and religious diversity, indicators of the spread in income distribution and geographic location, and a country's political fragmentation as measured by the number of its first-order administrative divisions. While most of the coefficients on these variables take a positive sign, only the point estimate on the ethnolinguistic fractionalization measure, a variable that is available for only a small share of the sample, is statistically different from zero. The number of a country's administrative units is also slightly (positively) correlated with central bank board size.

In comparison, there is only weak evidence that measures of a country's level of economic development or the degree of external openness influence MPC size; results are reported in Table 3. Reviewing the coefficients, there is only one relationship of reasonable statistical strength: landlocked countries have smaller boards. Broadly in line with this finding, we find that trade openness is consistently negatively associated with MPC size,

\footnotetext{
${ }^{30}$ As another test for possible non-linearities, we re-estimated all equations with squared values of the variables of interest entered; see below.
} 
although the coefficient is not statistically different from zero in any of the specifications. In contrast, most variables typically associated with economic and financial development and material well-being neither show the expected sign nor are they statistically significant.

The empirical results for indicators of a country's political regime, tabulated in Table 4, seem to suggest that well-established democratic institutions and countries with stronger governance performance are associated with larger central bank boards. In terms of statistical significance, however, results appear to be somewhat mixed. In the simple bivariate specification, none of the coefficients on measures of institutional quality is statistically different from zero. Still, for some variables, the estimated coefficients at least border conventional levels of significance, an impression that is also observable from the scatter plots (shown in the Appendix). Moreover, when we control for size and income, the estimated coefficients increase in magnitude and become statistically highly significant.

At a more detailed level, it turns out that the standard Polity IV scores (democracy, autocracy, polity), which comprise composite measures of institutionalized characteristics of the political regime, are weakly but consistently linked with MPC size across specifications. Countries with open and democratic political institutions tend to have large MPCs, while countries with autocratic structures have relatively small MPCs, though none of the nine coefficients is statistically different from zero. The estimates for the Freedom House measure on the state of civil liberties (political rights, civil rights) are not only supportive to this hypothesized relationship but also somewhat stronger statistically; the results indicate that "free" countries (as measured by low scores) have on average more members on their central bank boards than countries with a low freedom ranking. Finally, we experiment with several indicators on various dimensions of democracy, governance, and anti-corruption (voice and 
Table 3. Characterizing MPCs: Level of Development and Openness

\begin{tabular}{|l|l|l|l|l|}
\hline & Obs. & $\begin{array}{l}\text { Bivariate } \\
\text { ordered } \\
\text { probit }\end{array}$ & $\begin{array}{l}\text { Augmented } \\
\text { ordered } \\
\text { probit }\end{array}$ & $\begin{array}{l}\text { Probit with } \\
\text { binary dep. } \\
\text { variable }\end{array}$ \\
\hline Real GDP per capita (USD) & 83 & -0.006 & -0.02 & -0.0001 \\
$(0.01)$ & $(0.015)$ \\
\hline Real GDP per capita (PPP) & 80 & $\begin{array}{l}0.004 \\
(0.017)\end{array}$ & $\begin{array}{l}-0.006 \\
(0.017)\end{array}$ & $\begin{array}{l}0.009 \\
(0.018)\end{array}$ \\
\hline Human Development Index & 61 & 0.48 & 1.47 & 0.56 \\
& & $(0.79)$ & $(1.05)$ & $(1.01)$ \\
\hline Urbanization & 84 & 0.003 & 0.008 & 0.38 \\
& & $(0.005)$ & $(0.006)$ & $(0.65)$ \\
\hline M3 & 80 & -0.0007 & 0.0009 & 0.003 \\
& & $(0.0034)$ & $(0.0035)$ & $(0.004)$ \\
\hline Domestic Bank Credit & 80 & 0.0003 & -0.002 & -0.00002 \\
& & $(0.0023)$ & $(0.003)$ & $(0.00246)$ \\
\hline Trade Openness & 78 & -0.005 & -0.002 & -0.003 \\
& & $(0.003)$ & $(0.003)$ & $(0.004)$ \\
\hline Landlocked & 83 & $-0.57 *$ & $-0.51 \#$ & -0.45 \\
& & $(0.26)$ & $(0.28)$ & $(0.33)$ \\
\hline Business Cycle Correlation & 83 & 0.27 & 0.44 & 0.26 \\
& & $(0.41)$ & $(0.38)$ & $(0.50)$ \\
\hline
\end{tabular}

Note: Standard errors are in parentheses. ${ }^{* *}, *$ and $\#$ denote significant at the $0.01,0.05$ and 0.10 level, respectively. 
Table 4. Characterizing MPCs: Political Regime

\begin{tabular}{|c|c|c|c|c|}
\hline & Obs. & $\begin{array}{l}\text { Bivariate } \\
\text { ordered } \\
\text { probit } \\
\end{array}$ & $\begin{array}{l}\text { Augmented } \\
\text { ordered } \\
\text { probit } \\
\end{array}$ & $\begin{array}{l}\text { Probit with } \\
\text { binary dep. } \\
\text { variable }\end{array}$ \\
\hline Democracy & 76 & $\begin{array}{c}0.05 \\
(0.03)\end{array}$ & $\begin{array}{l}0.05 \\
(0.03) \\
\end{array}$ & $\begin{array}{l}0.06 \\
(0.04)\end{array}$ \\
\hline Autocracy & 76 & $\begin{array}{l}-0.07 \\
(0.05)\end{array}$ & $\begin{array}{l}-0.07 \\
(0.05)\end{array}$ & $\begin{array}{l}-0.06 \\
(0.05)\end{array}$ \\
\hline Polity & 76 & $\begin{array}{c}0.03 \\
(0.02)\end{array}$ & $\begin{array}{c}0.03 \\
(0.02)\end{array}$ & $\begin{array}{c}0.03 \\
(0.02)\end{array}$ \\
\hline Political Rights & 84 & $\begin{array}{l}-0.07 \\
(0.06)\end{array}$ & $\begin{array}{l}-0.12^{*} \\
(0.06)\end{array}$ & $\begin{array}{l}-0.09 \\
(0.07)\end{array}$ \\
\hline Civil Rights & 84 & $\begin{array}{l}-0.07 \\
(0.08)\end{array}$ & $\begin{array}{l}-0.16^{*} \\
(0.08)\end{array}$ & $\begin{array}{l}-0.08 \\
(0.09)\end{array}$ \\
\hline Economic Freedom & 63 & $\begin{array}{l}-0.10 \\
(0.18)\end{array}$ & $\begin{array}{l}0.12 \\
(0.21)\end{array}$ & $\begin{array}{l}-0.09 \\
(0.18)\end{array}$ \\
\hline Economic Security & 46 & $\begin{array}{c}0.47 \\
(0.72) \\
\end{array}$ & $\begin{array}{c}2.37^{*} \\
(1.17) \\
\end{array}$ & $\begin{array}{c}0.30 \\
(1.07)\end{array}$ \\
\hline Voice \& Accountability & 84 & $\begin{array}{c}0.18 \\
(0.16) \\
\end{array}$ & $\begin{array}{l}0.44 * * \\
(0.16)\end{array}$ & $\begin{array}{c}0.23 \\
(0.18) \\
\end{array}$ \\
\hline Political Stability & 82 & $\begin{array}{c}0.06 \\
(0.13)\end{array}$ & $\begin{array}{c}0.36^{*} \\
(0.14)\end{array}$ & $\begin{array}{c}0.18 \\
(0.16)\end{array}$ \\
\hline Government Effectiveness & 83 & $\begin{array}{c}0.12 \\
(0.15)\end{array}$ & $\begin{array}{l}0.62 * * \\
(0.19)\end{array}$ & $\begin{array}{c}0.22 \\
(0.17)\end{array}$ \\
\hline Regulatory Quality & 84 & $\begin{array}{c}0.14 \\
(0.17) \\
\end{array}$ & $\begin{array}{l}0.40^{*} \\
(0.19) \\
\end{array}$ & $\begin{array}{c}0.27 \\
(0.17) \\
\end{array}$ \\
\hline Rule of Law & 84 & $\begin{array}{c}0.08 \\
(0.14)\end{array}$ & $\begin{array}{l}0.71^{* *} \\
(0.24)\end{array}$ & $\begin{array}{c}0.18 \\
(0.16)\end{array}$ \\
\hline Deficit & 61 & $\begin{array}{l}-0.02 \\
(0.03)\end{array}$ & $\begin{array}{c}0.02 \\
(0.03)\end{array}$ & $\begin{array}{c}0.004 \\
(0.050)\end{array}$ \\
\hline Debt & 50 & $\begin{array}{c}0.009 * \\
(0.004)\end{array}$ & $\begin{array}{r}0.007 \# \\
(0.004) \\
\end{array}$ & $\begin{array}{c}0.011 \\
(0.007)\end{array}$ \\
\hline
\end{tabular}

Note: Standard errors are in parentheses. **, * and \# denote significant at the 0.01, 0.05 and 0.10 level, respectively. 
accountability, political stability and absence of violence, government effectiveness, regulatory quality, rule of law)—measures that were compiled by the World Bank. The results seem to support the idea that a better quality of governance is accompanied by larger MPCs. Most notably, the voice and accountability measure, which is an indicator of the extent to which citizens of a country are able to participate in the selection of their government, is significantly positively related to MPC size in the augmented model. ${ }^{31}$

In a final iteration, we find that larger government debt (in percent of GDP) is often associated with larger MPCs. However, the estimate is drawn from a relatively limited sample of countries, and no such relation can be found for the fiscal deficit.

Table 5 examines the association between the size of MPCs and other central bank features. We begin with several (binary) measures of central bank independence, taken from Lybek and Morris (2004) and a recent Bank of England survey among central banks (Fry et al., 2000). Overall, the evidence is mixed. Most of the legal measures obtained from Lybek and Morris, classifying different types of legal autonomy of a central bank, are uncorrelated with the number of board members. ${ }^{32}$ Some results based on Fry et al.'s (2000) independence scores, in contrast, indicate that more independent central banks have relatively larger boards, thereby providing mild support for Blinder (2006); these results, however, are derived from a smaller sample. ${ }^{33}$ Moreover, there is a positive correlation between the extent

\footnotetext{
${ }^{31}$ The indicator summarizes a number of aspects of the political process, civil liberties, and political rights.

${ }^{32}$ Note that different types of autonomy (goal autonomy, target autonomy, instrument autonomy, and limited or no autonomy) refers to the type of decisions the central bank determines, but that the quality of independence depends on a range of other factors discussed in, for instance, Lybek $(1998,1999)$.

${ }^{33}$ We also tried a number of alternative measures of central bank independence that are frequently used in the literature, without much success. For most of these measures, sample size gets extremely small when member countries of the euro area (which are not covered in our analysis) are removed.
} 
Table 5. Characterizing MPCs: Central Bank Characteristics

\begin{tabular}{|c|c|c|c|c|}
\hline & Obs. & $\begin{array}{l}\text { Bivariate } \\
\text { ordered } \\
\text { probit } \\
\end{array}$ & $\begin{array}{l}\text { Augmented } \\
\text { ordered } \\
\text { probit } \\
\end{array}$ & $\begin{array}{l}\text { Probit with } \\
\text { binary dep. } \\
\text { variable }\end{array}$ \\
\hline Central Bank Independence & 84 & $\begin{array}{l}-0.004 \\
(0.140)\end{array}$ & $\begin{array}{l}-0.10 \\
(0.15)\end{array}$ & $\begin{array}{l}0.05 \\
(0.18)\end{array}$ \\
\hline CB Independence Score & 59 & $\begin{array}{l}-0.004 \\
(0.009)\end{array}$ & $\begin{array}{r}0.02 * \\
(0.01)\end{array}$ & $\begin{aligned} 0.02 \# \\
(0.01)\end{aligned}$ \\
\hline Goal Independence & 84 & $\begin{array}{l}-0.26 \\
(0.32)\end{array}$ & $\begin{array}{l}-0.46 \\
(0.28)\end{array}$ & $\begin{array}{l}-0.04 \\
(0.37)\end{array}$ \\
\hline Price Stability Focus & 59 & $\begin{array}{l}-0.56 \\
(0.81)\end{array}$ & $\begin{array}{l}-0.39 \\
(1.11)\end{array}$ & $\begin{array}{l}-0.05 \\
(1.07)\end{array}$ \\
\hline Target Independence & 84 & $\begin{array}{c}0.17 \\
(0.23)\end{array}$ & $\begin{array}{c}0.15 \\
(0.24)\end{array}$ & $\begin{array}{l}-0.005 \\
(0.296)\end{array}$ \\
\hline Target Independence Score & 59 & $\begin{array}{l}-0.33 \\
(0.41)\end{array}$ & $\begin{array}{l}-0.46 \\
(0.44)\end{array}$ & $\begin{array}{l}-0.32 \\
(0.66)\end{array}$ \\
\hline Instrument Independence & 84 & $\begin{array}{c}0.13 \\
(0.25)\end{array}$ & $\begin{array}{c}0.28 \\
(0.26)\end{array}$ & $\begin{array}{c}0.23 \\
(0.30)\end{array}$ \\
\hline Instrument Independence Score & 59 & $\begin{array}{l}-0.04 \\
(0.53)\end{array}$ & $\begin{array}{l}1.24 * * \\
(0.42)\end{array}$ & $\begin{array}{l}1.45^{* *} \\
(0.60)\end{array}$ \\
\hline Limited or No Autonomy & 84 & $\begin{array}{l}-0.60 \# \\
(0.32)\end{array}$ & $\begin{array}{l}-0.70^{*} \\
(0.34)\end{array}$ & $\begin{array}{l}-0.77 \\
(0.59)\end{array}$ \\
\hline $\begin{array}{l}\text { Limited Central Bank Financing } \\
\text { of Government Deficit }\end{array}$ & 59 & $\begin{array}{l}-0.37 \\
(0.57)\end{array}$ & $\begin{array}{l}1.41^{* *} \\
(0.54)\end{array}$ & $\begin{array}{l}0.75 \\
(0.75)\end{array}$ \\
\hline $\begin{array}{l}\text { Authority over Exchange Rate } \\
\text { Policy }\end{array}$ & 84 & $\begin{array}{c}0.06 \\
(0.24)\end{array}$ & $\begin{array}{c}0.05 \\
(0.27)\end{array}$ & $\begin{array}{c}0.14 \\
(0.30)\end{array}$ \\
\hline $\begin{array}{l}\text { Goal Independence or Exchange } \\
\text { Rate Policy Authority }\end{array}$ & 84 & $\begin{array}{l}-0.16 \\
(0.25)\end{array}$ & $\begin{array}{l}-0.31 \\
(0.25)\end{array}$ & $\begin{array}{c}0.07 \\
(0.32)\end{array}$ \\
\hline Fixed Exchange Rate, RR & 84 & $\begin{array}{c}0.26 \\
(0.25) \\
\end{array}$ & $\begin{array}{c}0.43 \\
(0.28) \\
\end{array}$ & $\begin{array}{c}0.57 \\
(0.46) \\
\end{array}$ \\
\hline Floating Exchange Rate, RR & 84 & $\begin{array}{c}0.90^{*} \\
(0.37)\end{array}$ & $\begin{array}{c}0.57 \\
(0.50)\end{array}$ & $\begin{array}{l}7.71 * * \\
(0.16)\end{array}$ \\
\hline Fixed Exchange Rate, LYS & 84 & $\begin{array}{c}0.04 \\
(0.23)\end{array}$ & $\begin{array}{c}0.32 \\
(0.23)\end{array}$ & $\begin{array}{c}0.22 \\
(0.29)\end{array}$ \\
\hline Floating Exchange Rate, LYS & 84 & $\begin{array}{l}0.67 * * \\
(0.26)\end{array}$ & $\begin{array}{c}0.51 \# \\
(0.27)\end{array}$ & $\begin{array}{c}0.56 \# \\
(0.33)\end{array}$ \\
\hline Fixed Exchange Rate, IMF & 84 & $\begin{array}{l}-0.45 \# \\
(0.24) \\
\end{array}$ & $\begin{array}{l}-0.31 \\
(0.27) \\
\end{array}$ & $\begin{array}{l}-0.21 \\
(0.31) \\
\end{array}$ \\
\hline Floating Exchange Rate, IMF & 84 & $\begin{array}{c}0.40 \# \\
(0.23) \\
\end{array}$ & $\begin{array}{c}0.22 \\
(0.25)\end{array}$ & $\begin{array}{c}0.15 \\
(0.29) \\
\end{array}$ \\
\hline Term Length & 65 & $\begin{array}{l}-0.04 \\
(0.08)\end{array}$ & $\begin{array}{l}-0.12 \\
(0.08)\end{array}$ & $\begin{array}{l}-0.09 \\
(0.09)\end{array}$ \\
\hline Term Length in CB Law & 84 & $\begin{array}{c}0.22 \\
(0.23) \\
\end{array}$ & $\begin{array}{c}0.05 \\
(0.24) \\
\end{array}$ & $\begin{array}{c}0.18 \\
(0.36)\end{array}$ \\
\hline Staff & 84 & $\begin{array}{l}0.10 * * \\
(0.03)\end{array}$ & $\begin{array}{l}0.03^{* *} \\
(0.01)\end{array}$ & $\begin{array}{c}0.05^{*} \\
(0.02)\end{array}$ \\
\hline Log Staff & 84 & $\begin{array}{l}0.50 * * \\
(0.09)\end{array}$ & $\begin{array}{c}0.47^{* *} \\
(0.15)\end{array}$ & $\begin{array}{l}0.54^{* *} \\
(0.16)\end{array}$ \\
\hline Staff \% Population & 84 & $\begin{array}{l}-7.31 \\
(8.31)\end{array}$ & $\begin{array}{l}-2.04 \\
(7.77)\end{array}$ & $\begin{array}{r}-10.42 \\
(8.64)\end{array}$ \\
\hline Operating Expenditures & 65 & $\begin{array}{c}0.52 * * \\
(0.19)\end{array}$ & $\begin{array}{c}0.32 \\
(0.38)\end{array}$ & $\begin{array}{r}3.01 \# \\
(1.82)\end{array}$ \\
\hline
\end{tabular}


Table 5 (concluded). Characterizing MPCs: Central Bank Characteristics

\begin{tabular}{|l|l|l|l|l|}
\hline Log Operating Expenditures & 65 & $\begin{array}{l}0.28^{* *} \\
(0.09)\end{array}$ & $\begin{array}{l}0.41^{*} \\
(0.18)\end{array}$ & $\begin{array}{c}0.24 \# \\
(0.13)\end{array}$ \\
\hline Establishment Year & 84 & -0.0005 & -0.0009 & -0.0005 \\
& & $(0.0020)$ & $(0.0021)$ & $(0.0030)$ \\
\hline Establishment Year $(>\mathbf{1 9 0 0 )}$ & 77 & -0.008 & -0.006 & -0.006 \\
& & $(0.006)$ & $(0.007)$ & $(0.006)$ \\
\hline
\end{tabular}

Note: Standard errors are in parentheses. **, * and \# denote significant at the 0.01, 0.05 and 0.10 level, respectively. 
to which there are limits on central bank financing of government deficits and MPC size (in the augmented specification).

A country's exchange rate regime appears to be a useful proxy for the complexity of the central bank's monetary policy strategy. Based on the most commonly used de jure and de facto exchange rate regime classifications, we have compiled binary measures for both hard-fixed and fully free-floating exchange rates (leaving the various intermediate forms of exchange rate pegs and inconclusive regimes as a control group). While the coefficients on the dummy variables for a fixed exchange rate regime (which are expected to be negative) are rarely significant in our regressions, the estimated coefficients on the floating exchange rate dummies often take on a significantly positive sign, implying that countries with flexible exchange rates tend to have larger boards.

Concerning the term length of board members, we explore two features: the (de jure) term length in years, and whether the term length is stipulated in the central bank law. Neither coefficient is statistically different from zero. ${ }^{34}$

Finally, we find a significant (positive) correlation between the size of a central bank and the size of the central bank board. Central banks with more staff and higher operating expenditures (and, thus, possibly more functions) also operate larger MPCs, while recently established central banks tend to have smaller boards, although only the former relations are significant at conventional statistical levels.

\footnotetext{
${ }^{34}$ Our measure of term length for MPC members is obtained from Lybek and Morris (2004); the measure is highly positively correlated with equivalent information for central bank governors that is reported in the Morgan Stanley Central Bank Directory.
} 
Table 6. Quadratic Results

\begin{tabular}{|c|c|c|c|c|}
\hline Variable & Coefficient 1 & Std. dev. & Coefficient 2 & Std. dev. \\
\hline Population & $0.018 * *$ & $(0.007)$ & $-0.00004 \#$ & $(0.00002)$ \\
\hline Area & 0.172 & $(0.139)$ & 0.005 & $(0.012)$ \\
\hline Real GDP (USD) & 0.459 & $(0.362)$ & -0.033 & $(0.035)$ \\
\hline Real GDP (PPP) & $0.850 \#$ & $(0.443)$ & -0.069 & $(0.042)$ \\
\hline Ethnolinguistic Fractionalization & -0.218 & $(2.228)$ & 1.538 & $(2.566)$ \\
\hline Ethnic Fractionalization, CH & -0.010 & $(0.021)$ & 0.0002 & $(0.0002)$ \\
\hline Ethnic Fractionalization, ADEKW & -0.666 & $(2.733)$ & 1.036 & $(3.197)$ \\
\hline Linguistic Diversity & -4.954 & $(1.605)$ & 0.818 & $(1.772)$ \\
\hline Linguistic Fractionalization & -1.484 & $(1.609)$ & 1.712 & $(1.876)$ \\
\hline Religious Fractionalization & -2.340 & $(2.030)$ & 3.652 & $(2.364)$ \\
\hline Gini Coefficient & 0.031 & $(0.071)$ & -0.0004 & $(0.0008)$ \\
\hline Geographic Dispersion & 0.311 & $(3.785)$ & -0.205 & $(3.494)$ \\
\hline Administrative Divisions & $0.024 *$ & $(0.011)$ & $-0.0001 *$ & $(0.00005)$ \\
\hline Real GDP per capita (USD) & 0.030 & $(0.038)$ & -0.001 & $(0.002)$ \\
\hline Real GDP per capita (PPP) & 0.043 & $(0.042)$ & -0.001 & $(0.002)$ \\
\hline Human Development Index & 1.027 & $(7.154)$ & -0.411 & $(5.479)$ \\
\hline Urbanization & 0.026 & $(0.020)$ & -0.0002 & $(0.0002)$ \\
\hline M3 & 0.005 & $(0.010)$ & -0.00003 & $(0.00005)$ \\
\hline Domestic Bank Credit & -0.005 & $(0.006)$ & 0.00002 & $(0.00002)$ \\
\hline Trade Openness & $-0.016 \#$ & $(0.008)$ & 0.00005 & $(0.00003)$ \\
\hline Business Cycle Correlation & 0.526 & $(0.416)$ & -0.931 & $(1.322)$ \\
\hline Democracy & 0.083 & $(0.136)$ & -0.003 & $(0.014)$ \\
\hline Autocracy & -0.155 & $(0.130)$ & 0.011 & $(0.016)$ \\
\hline Polity & 0.033 & $(0.024)$ & -0.00009 & $(0.0041)$ \\
\hline Political Rights & 0.096 & $(0.287)$ & -0.023 & $(0.038)$ \\
\hline Civil Rights & 0.553 & $(0.411)$ & -0.086 & $(0.054)$ \\
\hline Economic Freedom & 0.427 & $(1.969)$ & -0.040 & $(0.150)$ \\
\hline Economic Security & $4.039 *$ & $(2.004)$ & $-3.713 \#$ & $(2.029)$ \\
\hline Voice \& Accountability & 0.196 & $(0.154)$ & -0.255 & $(0.165)$ \\
\hline Political Stability & 0.014 & $(0.140)$ & -0.185 & $(0.127)$ \\
\hline Government Effectiveness & $0.330^{*}$ & $(0.140)$ & $-0.307^{*}$ & $(0.128)$ \\
\hline Regulatory Quality & 0.138 & $(0.173)$ & $-0.252 \#$ & $(0.136)$ \\
\hline Rule of Law & $0.399 * *$ & $(0.145)$ & $-0.408 * *$ & $(0.146)$ \\
\hline Deficit & -0.017 & $(0.024)$ & 0.004 & $(0.004)$ \\
\hline Debt & $0.029 * *$ & $(0.011)$ & $-0.0002 *$ & $(0.00007)$ \\
\hline Central Bank Independence & 1.251 & $(0.650)$ & -0.233 & $(0.126)$ \\
\hline CB Independence Score & 0.072 & $(0.045)$ & -0.0004 & $(0.0003)$ \\
\hline Price Stability Focus & 1.272 & $(2.055)$ & -0.579 & $(1.760)$ \\
\hline Target Independence Score & $3.192 *$ & $(1.242)$ & $-3.087 *$ & $(1.275)$ \\
\hline Instrument Independence Score & 2.212 & $(1.861)$ & -0.786 & $(1.646)$ \\
\hline Lim. CB Financing of Gov’t Deficit & 7.912\# & $(4.505)$ & $-5.437 \#$ & $(3.177)$ \\
\hline Term Length & $-0.590 * *$ & $(0.204)$ & $0.040 * *$ & $(0.012)$ \\
\hline Staff & $0.131 * *$ & $(0.043)$ & $-0.001 \#$ & $(0.0005)$ \\
\hline Staff \% Population & -1.902 & $(21.51)$ & -73.4 & $(208.7)$ \\
\hline Staff \% Population & -1.902 & $(21.51)$ & -73.4 & $(208.7)$ \\
\hline Operating Expenditures & 1.909\# & $(1.000)$ & $-0.0004 \#$ & $(0.0003)$ \\
\hline
\end{tabular}




\section{Nonlinear Specification}

In most cases, the scatter plots collected in Appendix IV suggest that linear models capture the correlation between MPC size and its possible determinants reasonably well. Still, to allow for possible non-linearities, we also estimate our ordered probit models with quadratic terms.

Table 6 presents the results. Reassuringly, almost all variables for which we find a significant non-linear effect on MPC size were also relevant determinants of MPC size in the linear specification; that is, they produced significant coefficients in at least one of the specifications reported in Tables 1-5. In addition, the target independence score becomes a significant determinant of MPC size, thereby reinforcing the bivariate results for other indicators of central bank independence. Other variables, in contrast, lose their significance in the non-linear model, such as real GDP and ethnolinguistic fractionalization.

A second observation is that the majority of variables display, if anything, a concave relationship with MPC size. ${ }^{35}$ This holds for population, administrative divisions, economic security, government effectiveness, rule of law, debt, and the number of central bank staff. The estimation results imply that the marginal benefits of increasing MPC size are declining in the relevant country characteristic. That is, a given increase in population size, for instance, seems to have a smaller impact on MPC size at lower population levels.

Our results for the term length of board members deviate from these two general findings. The term length of board members is significantly associated with MPC size only in

\footnotetext{
${ }^{35}$ Using the ordered probit coefficients can be misleading in this respect, but we find very similar results based on the OLS models. Results are not shown.
} 
the non-linear specification. Also, the relationship is convex rather than concave. As illustrated in Appendix V, board members tend to have longer legislated terms in both relatively large and relatively small MPCs.

\section{E. Multivariate Results}

Next, we aim to explain cross-country differences in MPC size by combining various explanatory variables. The aim of this exercise is twofold. First, we are interested in exploring the robustness of our empirical findings, after controlling for the effect of other factors on MPC size. Second, we want to explore the empirical fit of our specification (i.e., the extent to which we are able to explain the variation in MPC size in our sample).

Our empirical approach is essentially guided by data availability; it is constrained by possible multicollinearity. Specifically, we select from each group of determinants a representative variable that has a particularly strong bivariate correlation with central bank board size and is available for a large fraction of the sample. To this baseline specification, we then add other variables of intrinsic interest.

Table 7 reports the results. The first column reports the benchmark specification which jointly includes a measure of country size (population), level of economic and financial development (real per capita income), openness (landlockedness), political regime (voice and accountability), and central bank size (staff; we obtain similar results for operating expenditures) to explain the size of the board. As shown, the results indicate that country size, a democratic political regime, and a large number of central bank staff are associated with larger MPCs, while landlocked and/or richer countries tend to have smaller boards. More notably, compared with the bivariate results, all variables (except for landlockedness) 
Table 7. Empirical Determinants of MPC Size

\begin{tabular}{|c|c|c|c|c|c|c|c|c|}
\hline Population & $\begin{array}{l}0.744 * * \\
(0.254)\end{array}$ & & $\begin{array}{c}0.533 \\
(0.325)\end{array}$ & $\begin{array}{c}0.730 \\
(0.456)\end{array}$ & $\begin{array}{r}0.599 * \\
(0.263)\end{array}$ & $\begin{array}{l}0.874 * * \\
(0.278)\end{array}$ & $\begin{array}{l}0.908^{*} \\
(0.435)\end{array}$ & $\begin{array}{l}1.540 * * \\
(0.394)\end{array}$ \\
\hline Area & & $\begin{array}{l}0.186^{*} \\
(0.081) \\
\end{array}$ & & & & & & \\
\hline $\begin{array}{l}\text { Real GDP per } \\
\text { capita (USD) }\end{array}$ & $\begin{array}{l}-0.431^{*} \\
(0.175)\end{array}$ & $\begin{array}{l}-0.463 * * \\
(0.175)\end{array}$ & $\begin{array}{l}-0.473^{*} \\
(0.200)\end{array}$ & $\begin{array}{l}-0.593 * * \\
(0.227)\end{array}$ & $\begin{array}{l}-0.389^{*} \\
(0.174)\end{array}$ & $\begin{array}{l}-0.608 * * \\
(0.185)\end{array}$ & $\begin{array}{l}-0.697 * * \\
(0.236)\end{array}$ & $\begin{array}{l}-0.378 \\
(0.244)\end{array}$ \\
\hline Landlocked & $\begin{array}{l}-0.428 \\
(0.280)\end{array}$ & $\begin{array}{l}-0.485 \# \\
(0.283) \\
\end{array}$ & $\begin{array}{l}-0.563 \# \\
(0.294) \\
\end{array}$ & $\begin{array}{l}-0.990 * * \\
(0.368)\end{array}$ & $\begin{array}{l}-0.433 \\
(0.279) \\
\end{array}$ & $\begin{array}{l}-0.544 \# \\
(0.320)\end{array}$ & $\begin{array}{l}-0.842 * * \\
(0.320)\end{array}$ & $\begin{array}{l}-0.931 * * \\
(0.415) \\
\end{array}$ \\
\hline $\begin{array}{l}\text { Voice \& } \\
\text { Accountability }\end{array}$ & $\begin{array}{l}0.425 * * \\
(0.156)\end{array}$ & $\begin{array}{c}0.382^{*} \\
(0.166)\end{array}$ & $\begin{array}{c}0.386^{*} \\
(0.177)\end{array}$ & $\begin{array}{c}0.395 * \\
(0.158)\end{array}$ & $\begin{array}{c}0.375^{*} \\
(0.154)\end{array}$ & $\begin{array}{l}0.707 * * \\
(0.212)\end{array}$ & $\begin{array}{c}0.429 * \\
(0.179)\end{array}$ & $\begin{array}{l}0.497 * * \\
(0.253)\end{array}$ \\
\hline Staff & $\begin{array}{l}0.385^{* *} \\
(0.131)\end{array}$ & $\begin{array}{c}0.709 \\
(0.464)\end{array}$ & $\begin{array}{l}0.444 * * \\
(0.169)\end{array}$ & $\begin{array}{r}0.376 \# \\
(0.217)\end{array}$ & $\begin{array}{l}0.410^{* *} \\
(0.120)\end{array}$ & $\begin{array}{l}0.360 * * \\
(0.087)\end{array}$ & $\begin{array}{c}0.345 \# \\
(0.200)\end{array}$ & $\begin{array}{c}0.765 \\
(0.508)\end{array}$ \\
\hline Trade Openness & & & $\begin{array}{l}-0.004 \\
(0.003) \\
\end{array}$ & & & & & \\
\hline $\begin{array}{l}\text { Business Cycle } \\
\text { Correlation }\end{array}$ & & & $\begin{array}{c}0.573 \\
(0.447)\end{array}$ & & & & & \\
\hline $\begin{array}{l}\text { CB Independence } \\
\text { Score }\end{array}$ & & & & $\begin{array}{l}0.020^{*} \\
(0.009)\end{array}$ & & & & \\
\hline $\begin{array}{l}\text { Float'g Exchange } \\
\text { Rate, LYS }\end{array}$ & & & & & $\begin{array}{r}0.482 \# \\
(0.284) \\
\end{array}$ & & & \\
\hline Term Length & & & & & & $\begin{array}{l}-0.457 \# \\
(0.271)\end{array}$ & & \\
\hline $\begin{array}{l}\text { Term Length } \\
\text { Squared }\end{array}$ & & & & & & $\begin{array}{c}0.022 \\
(0.016) \\
\end{array}$ & & \\
\hline $\begin{array}{l}\text { Lim. CB Finan- } \\
\text { cing of Gov't Def. }\end{array}$ & & & & & & & $\begin{array}{c}1.109 \# \\
(0.601)\end{array}$ & \\
\hline $\begin{array}{l}\text { Ethnolinguistic } \\
\text { Fractionalization }\end{array}$ & & & & & & & & $\begin{array}{l}1.485^{*} \\
(0.618)\end{array}$ \\
\hline & & & & & & & & \\
\hline $\begin{array}{l}\text { Number } \\
\text { Observations }\end{array}$ & 83 & 83 & 78 & 53 & 83 & 64 & 53 & 50 \\
\hline Count R2 & 0.542 & 0.530 & 0.551 & 0.604 & 0.530 & 0.563 & 0.604 & 0.580 \\
\hline Pseudo-R2 & 0.334 & 0.568 & 0.368 & 0.492 & 0.356 & 0.477 & 0.469 & 0.431 \\
\hline
\end{tabular}

Notes: Ordered probit regression. Dependent variable is board size index. Pseudo- $\mathrm{R}^{2}$ is the McKelvey and Zavoina $\mathrm{R}^{2}$. Standard errors are in parentheses. **, * and \# denote significant at the $0.01,0.05$ and 0.10 level, respectively. 
remain economically relevant and statistically highly significant. Finally, it should also be noted that our estimation results are derived from a still large sample of 83 observations. While the significance levels of individual variables later vary with the set of regressors (and sample size), the benchmark estimates generally turn out to be reasonably robust.

Adding other control variables yields further insights. In column two, we experiment with an alternative control for country size, replacing population with land area. This modification has little effect on the overall estimation results, though the empirical fit appears to be somewhat stronger for some $\mathrm{R}^{2}$-measures. In the remaining columns, we report results for other variables of theoretical interest. Among those variables, the strongest results are found for central bank independence and ethnolinguistic fractionalization; the estimated coefficients on these variables take on the expected sign and are statistically highly significant. Also the exchange rate regime and the degree to which there are limits to central bank financing of government debt appear to play (at least marginally) a significant role in explaining MPC size in a multivariate framework. ${ }^{36}$ In all cases, the results in Table 7 confirm the (previously reported) direction of the bivariate relationship. Openness and the correlation of the national with the world business cycle, in contrast, remain unrelated to MPC size.

Statistically, the overall fit of the multivariate models is encouraging. Pseudo- $\mathrm{R}^{2}$ values (as measured by the McKelvey and Zavoina method) are between 0.3 and 0.6. An alternative measure, the Count $\mathrm{R}^{2}$, is generally even higher (in the 0.5 to 0.6 range),

\footnotetext{
${ }^{36}$ Government debt, which played a role in the bivariate setup, does not show a significant influence on MPC size in the multivariate model.
} 
indicating that we are able to explain a considerable share of the variation in MPC size across countries. $^{37}$

\section{Conclusions}

Recent research emphasizes the importance of central bank design for the success of monetary policy. One of the features that have received particular interest is the membership size of the central bank's decision-making body — that is, how many people should decide whether to take measures to achieve a specified monetary policy target?

In theory, the optimal size of an MPC depends on the costs and benefits of changing membership size. On the benefit side, larger MPCs promise improvements in information processing along the lines of Condorcet's jury theorem. At the same time, decision making typically becomes more difficult and time consuming as the number of MPC members increases. Also, members may have a stronger incentive to "freeride" on the informationprocessing efforts of others in larger MPCs. Since factors affecting optimal board size are likely to differ across countries (e.g., the information-processing requirement might vary with the size and diversity of the economy), it seems reasonable to assume also that "the efficient size of a policy committee might vary across countries" (Goodfriend 2005, p. 85).

Around the world, central bank boards do indeed come in different sizes. In New Zealand, for instance, the governor alone is responsible for policy-making, while the European Central Bank (ECB) Governing Council currently comprises 19 members. Moreover, the pending increase in euro area membership has triggered a preemptive ECB

\footnotetext{
${ }^{37}$ As a robustness check, we also performed (unreported) OLS regressions. While the coefficient estimates
} (continued...) 
reform that generally limits the overall number of voting members to 21 . This, however, still seems to be a relatively large number compared with the membership size of other central bank decision-making bodies such as the U.S. Federal Reserve's Federal Open Market Committee. The average MPC in our sample of central banks has 7-9 members.

In this paper, we characterize differences in the structure of central bank governance. Our analysis is based on a dataset that covers the (de jure) membership size of 84 central bank boards around the world at the end of 2003 that make decisions on whether to increase or decrease interest rates to achieve a specified target. ${ }^{38} \mathrm{We}$ find that board size is indeed significantly and plausibly correlated to various country and central bank characteristics. For instance, MPC size tends to increase with country size and population heterogeneity, thereby providing empirical support for the notion that information-processing requirements affect central bank board size. There is also evidence that MPC size is correlated to political institutions, with more democratic countries having, on average, larger boards. For some variables, we find a hump-shaped effect on MPC size.

Finally, although the size of the central bank's policy committee has been the focus of much debate recently, there are indications that it should not be viewed as independent of other features of central bank design. MPC size is often associated with other central bank characteristics. For instance, central banks tend to have larger MPCs if they have more staff or higher operational expenditure. More importantly, countries with floating exchange rate regimes, which typically have more complicated monetary policy frameworks, also seem to operate larger boards. Along similar lines, we find that more independent central banks often 
have larger MPCs. Viewed in conjunction with the results discussed previously, this suggests that the institutional setup of central banks may indeed be tailored to reflect country-specific factors.

38 In a companion paper, Berger and Nitsch (2007), we examine the effect of various features of MPC design on the outcome of monetary policy. 


\section{REFERENCES}

Baldwin, Richard, Erik Berglöf, Francesco Giavazzi, and Mika Widgren, 2001, "Preparing the ECB for Enlargement," CEPR Policy Paper No. 6 (London: Center for Economic Policy Research).

Barber, Tony, 2001, “Casting Light on the ECB,” Financial Times Online, September 6.

Berger, Helge, 1997, “The Bundesbank's Path to Independence: Evidence from the 1950's," Public Choice, Vol. 93 No. (3-4), pp. 427-53.

_ 2006, "Optimal Central Bank Design: Benchmarks for the ECB," Review of International Organizations, Vol. 1 No. (3), pp. 207-335.

— Atlantic Economic Journal, Vol. 30 No. (3), pp. 1-20.

_ EU Enlargement, ed. by Helge Berger and Thomas Moutos (Cambridge, Massachusetts: MIT Press), pp. 29-66.

Berger, Helge, Sylvester Eijffinger, and Jakob de Haan, 2001, "Central Bank Independence: An Update of Theory and Evidence,” Journal of Economic Surveys, Vol. 15 No. (1), pp. 3-40.

Berger, Helge and Volker Nitsch, 2007, "Too Many Cooks? Committees in Monetary Policy" (unpublished); Freie Universität Berlin.

Berk, Jan Marc, and Beata K. Bierut, 2004, "The Effects of Learning in Interactive Monetary Policy Committees," Netherlands Central Bank, MEB Series No. 2004-01 (Amsterdam: De Netherlandsche Bank).

Blinder, Alan, 1998, Central Banking in Theory and Practice (Cambridge, Massachusetts: MIT Press).

__ 2006, "Monetary Policy by Committee: Why and How?" DNB Working Paper No. 90 (Amsterdam: De Netherlandsche Bank).

and John Morgan, 2005, “Are Two Heads Better Than One? Monetary Policy by Committee," Journal of Money, Credit and Banking, Vol. 37 No. (5), pp. 798-811.

Chappell, Henry W. Jr., Rob Roy McGregor, and Todd Vermilyea, 2004, "Majority Rule, Consensus Building, and the Power of the Chairman: Arthur Burns and the FOMC," Journal of Money, Credit, and Banking, Vol. 36 No. (3), pp. 407-22. 
D’Amato, Marcello, and Riccardo Martina, 2005, "Credibility and Commitment of Monetary Policy in Open Economies," European Journal of Political Economy. Vol. 21 No. (4), pp. 872-902.

Deutsche Bundesbank, 1992, "Restructuring the Bundesbank," Monthly Report. (August): pp. $48-53$.

European Central Bank (ECB), 2003, "The Adjustment of Voting Modalities in the Governing Council," Monthly Bulletin. (May): pp. 73-83.

Fry, Maxwell, DeAnne Julius, Lavan Mahadeva, Sandra Roger, and Gabriel Sterne, 2000, "Key Issues in the Choice of Monetary Policy Framework," in Lavan Mahadeva and Gabriel Sterne (eds.) Monetary Frameworks in a Global Context. (London: Routledge), pp. 1-216.

Fujiki, Hiroshi, 2005, "The Monetary Policy Committee and the Incentive Problem: A Selective Survey," Monetary and Economic Studies. (October): pp. 37-82.

Gerlach-Kristen, Petra, 2006, "Monetary Policy Committees and Interest-Rate Setting," European Economic Review. Vol. 50 No. (2), pp. 487-507.

Gerling, Kerstin, Hans Peter Grüner, Alexandra Kiel, and Elisabeth Schulte, 2005, "Information Acquisition and Decision Making in Committees: A Survey," European Journal of Political Economy. Vol. 21 No. (3), pp. 563-97.

Goodfriend, Marvin, 2005, "Comment on Fujiki," Monetary and Economic Studies. (October): pp. 83-87.

Hermalin, Benjamin E., and Michael S. Weisbach, 2001, "Boards of Directors as an Endogenously Determined Institution: A survey of the Economic Literature," NBER Working Paper \#8161 (Cambridge: National Bureau of Economic Research).

International Monetary Fund (IMF), 2003, Annual Report, Appendix II (Washington).

Ize, Alain, 2006, "Spending Seigniorage: Do Central Banks Have a Governance Problem?" IMF Working Paper 06/58 (Washington: International Monetary Fund).

Levy-Yeyati, Eduardo, and Sturzenegger, Federico, 2005, Classifying Exchange Rate Regimes: Deeds vs. Words, European Economic Review, Vol. 49 No. (6), pp. 160335 .

Lombardelli, Clare, James Proudman, and James Talbot, 2005, "Committees versus Individuals: An Experimental Analysis of Monetary Policy Decision Making," International Journal of Central Banking. Vol. 1 No. (1), pp. 181-205. 
Lybek, Tonny, 1998, "Elements of Central Bank: Autonomy and Accountability," Monetary and Exchange Affairs Department Operational Paper No. 98/1 (Washington: International Monetary Fund).

, 1999, "Central Bank Autonomy, and Inflation and Output Performance in the Baltic States, Russia, and other Countries of the Former Soviet Union, 1995-97," IMF Working Paper No. 99/4 (Washington: International Monetary Fund).

_ and JoAnne Morris, 2004, "Central Bank Governance: A Survey of Boards and Arrangements," IMF Working Paper 04/226 (Washington: International Monetary Fund).

Meade, Ellen, and Nathan Sheets, 2005, "Regional Influences on FOMC Voting Patterns," Journal of Money, Credit, and Banking. Vol. 37 No. (4), pp. 661-677.

Méon, Pierre-Guillaume, 2006, "Majority Voting with Stochastic Preferences: The Whims of a Committee are Smaller than the Whims of Its Members," Working Paper No. 06-05, RS Dulbea, Université Libre de Bruxelles.

Mirzoev, Tokhir, 2004, "Limited Commitment, Inaction and Optimal Monetary Policy," Ohio State University.

Posen, Adam, 1995, "Declarations Are Not Enough: Financial Sector Sources of Central Bank Independence," in Ben Bernanke and Julio Rotenberg (eds.) NBER Macroeconomics Annual 1995 (Cambridge: MIT Press).

Reinhart, Carmen, and Kenneth Rogoff, 2004, "The Modern History of Exchange Rate Arrangements: A Reinterpretation," Quarterly Journal of Economics, Vol. 119 No. (1), pp. 1-48.

Riboni, Alessandro, and Francisco Ruge-Murcia, 2006, "The Dynamic (In)efficiency of Monetary Policy by Committee," University of Montreal.

Rogoff, Kenneth, 1985, "The Optimal Degree of Commitment to an Intermediate Monetary Target," Quarterly Journal of Economics. Vol. 100 No. (4), pp. 1169-1190.

Romer, David, 1993, "Openness and Inflation: Theory and Evidence," Quarterly Journal of Economics. Vol. 108 No. (4), pp. 869-901.

Rose, Andrew K, 2006, "Size Really Doesn't Matter: In Search of a National Scale Effect," Journal of the Japanese and International Economies. Vol. 20 No. (4), pp. 482-507.

Schein, Edgar H., 1999, Process Consultation Revisited, Addison-Wesley. 
Sibert, Anne, 2006, “Central Banking by Committee,” DNB Working Paper No. 91. (Amsterdam: De Netherlandsche Bank).

Tuladhar, Anita, 2005, "Governance Structures and Decision-Making Roles in Inflation Targeting Central Banks," IMF Working Paper WP/05/183 (Washington: International Monetary Fund).

Vandenbussche, Jerome, 2006, "Preference and Judgment Aggregation in Monetary Policy Committees: A Survey," IMF Working Paper WP/06/277 (Washington: International Monetary Fund).

Waller, Christopher, 1989, "Macroeconomic Policy Games and Central Bank Politics," Journal of Money, Credit and Banking. Vol. 21 No. (4), pp. 422-31.

— 1992, "A Bargaining Model of Partisan Appointments to the Central Bank," Journal of Monetary Economics. Vol. 29 No. (3), pp. 411-28.

_ 2002, "Policy Boards and Policy Smoothing," Quarterly Journal of Economics. Vol. 115 No. (1), pp. 305-39.

and Carl Walsh, 1996, "Central Bank Independence, Economic Behavior, and Optimal Term Length,” American Economic Review. Vol. 85 No. (5), pp. 1139-54.

Woodford, Michael, 2003, Interest and Prices: Foundations of a Theory of Monetary Policy (Princeton, New Jersey: Princeton University Press). 
APPENDIX I. COUNTRIES IN THE SAMPLE

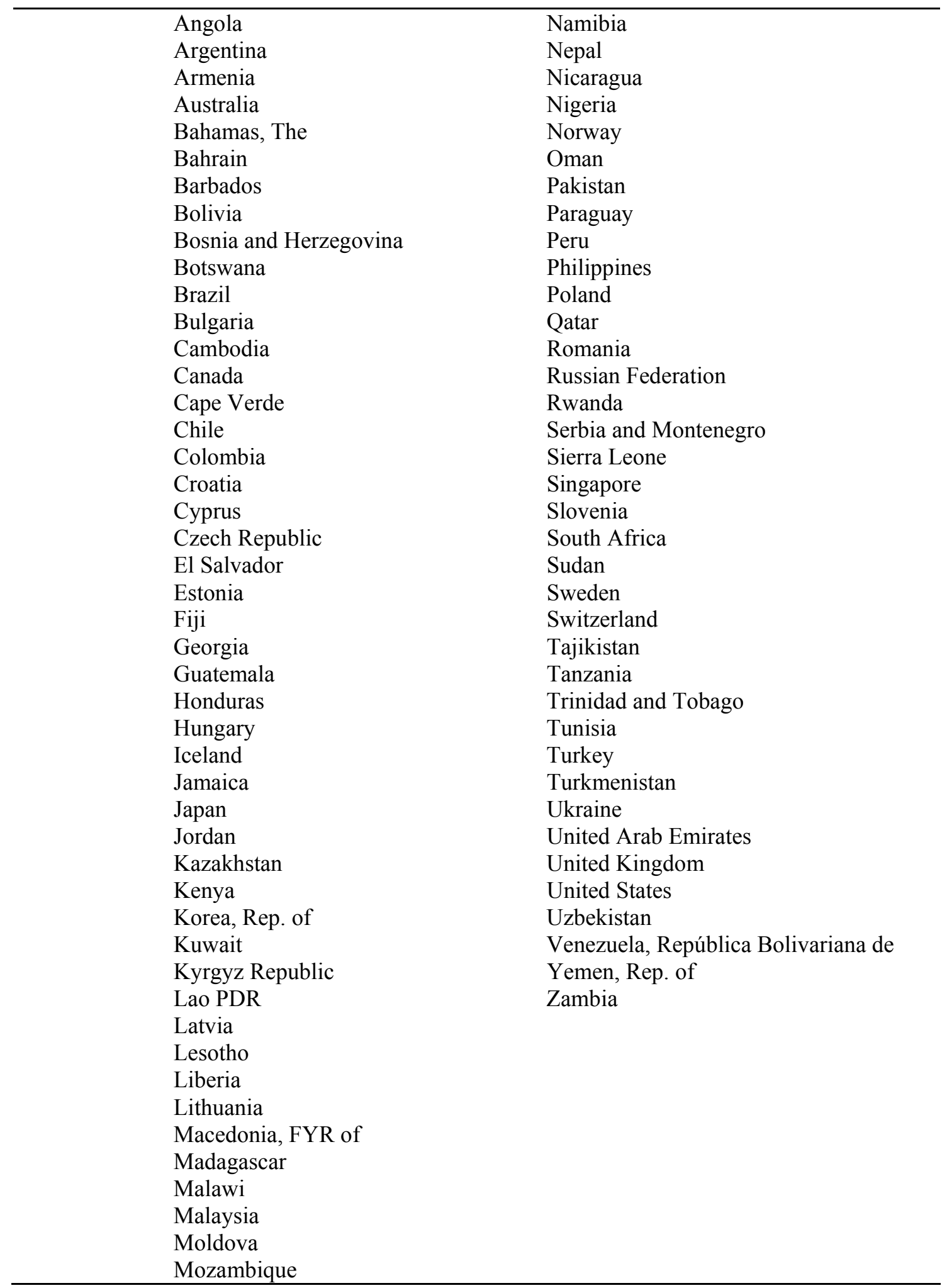




\section{DEFINITIONS AND SOURCES OF VARIABLES}

\begin{tabular}{|c|c|c|}
\hline Variable & Description & Source \\
\hline MPC & Board size index; implementation board & $\begin{array}{l}\text { Lybek and } \\
\text { Morris }\end{array}$ \\
\hline Population & Total population & Rose \\
\hline Area & Land area & Rose \\
\hline Real GDP (USD) & Real GDP in US dollar & Rose \\
\hline Real GDP (PPP) & Real GDP in PPP terms & Rose \\
\hline Ethnolinguistic Fractionalization & Ethnolinguistic Fractionalization, Mauro & Rose \\
\hline Ethnic Fractionalization, CH & $\begin{array}{l}\text { Ethnic Fractionalization, Collier \& } \\
\text { Hoeffler }\end{array}$ & Rose \\
\hline $\begin{array}{l}\text { Ethnic Fractionalization, } \\
\text { ADEKW }\end{array}$ & Ethnic Fractionalization, Alesina et al. & Rose \\
\hline Linguistic Diversity & Linguistic Diversity, Ethnologue & Rose \\
\hline Linguistic Fractionalization & Linguistic Fractionalization, Alesina et al. & Rose \\
\hline Religious Fractionalization & $\begin{array}{l}\text { Religious Fractionalization, Collier \& } \\
\text { Hoeffler }\end{array}$ & Rose \\
\hline Gini Coefficient & Gini Coefficient, CIA World Factbook & Rose \\
\hline Geographic Dispersion & $\begin{array}{l}\text { Geographic Dispersion, Collier \& } \\
\text { Hoeffler }\end{array}$ & Rose \\
\hline Administrative Divisions & $\begin{array}{l}\text { Number of first-order administrative } \\
\text { divisions }\end{array}$ & $\begin{array}{l}\text { CIA World } \\
\text { Factbook }\end{array}$ \\
\hline Real GDP per capita (USD) & Real GDP per capita in US dollar, WDI & Rose \\
\hline Real GDP per capita (PPP) & Real GDP per capita in PPP terms, WDI & Rose \\
\hline Human Development Index & Human development index, UNDP & Rose \\
\hline Urbanization & Urban population/Total population, WDI & Rose \\
\hline M3 & M3/GDP, WDI & Rose \\
\hline Domestic Bank Credit & Domestic bank credit/GDP, WDI & Rose \\
\hline Trade Openness & (Exports+Imports)/GDP, WDI & Rose \\
\hline Landlocked & Dummy $=1$ if country is landlocked & Rose \\
\hline Business Cycle Correlation & $\begin{array}{l}\text { Correlation with world GDP, 20-year } \\
\text { average }\end{array}$ & IFS \\
\hline Democracy & $\begin{array}{l}\text { Democracy index, Polity IV }(10= \\
\text { democratic) }\end{array}$ & Rose \\
\hline Autocracy & $\begin{array}{l}\text { Autocracy index, Polity IV }(10= \\
\text { autocratic) }\end{array}$ & Rose \\
\hline Polity & $\begin{array}{l}\text { Polity index, Polity IV }(-10=\text { autocratic; } \\
10=\text { democratic })\end{array}$ & Rose \\
\hline Political Rights & Political rights index, Freedom House & Rose \\
\hline Civil Rights & Civil rights index, Freedom House & Rose \\
\hline Economic Freedom & Freedom status, Freedom House & Rose \\
\hline Economic Security & Economic security index, ILO & Rose \\
\hline Voice \& Accountability & Voice \& Accountability, World Bank & Rose \\
\hline Political Stability & Political Stability, World Bank & Rose \\
\hline Government Effectiveness & Government Effectiveness, World Bank & Rose \\
\hline Regulatory Quality & Regulatory Quality, World Bank & Rose \\
\hline Rule of Law & Rule of Law, World Bank & Rose \\
\hline
\end{tabular}




\begin{tabular}{|c|c|c|}
\hline Deficit & $\begin{array}{l}\text { Overall budget balance/GDP, 10-year } \\
\text { average }\end{array}$ & WDI \\
\hline Debt & $\begin{array}{l}\text { Central government debt/GDP, 20-year } \\
\text { average }\end{array}$ & WDI \\
\hline Central Bank Independence & $\begin{array}{l}\text { Summary index }(\text { goal }=1 ; \text { target }=2 ; \\
\text { instrument }=3 ; \text { other }=4)\end{array}$ & $\begin{array}{l}\text { Lybek and } \\
\text { Morris }\end{array}$ \\
\hline CB Independence Score & Independence score $(0=$ low; $100=$ high $)$ & Fry et al. (BoE) \\
\hline Goal Independence & Dummy $=1$ if CB has goal independence & $\begin{array}{l}\text { Lybek and } \\
\text { Morris }\end{array}$ \\
\hline Price Stability Focus & $\begin{array}{l}\text { Statutory/legal objectives focus on price } \\
\text { stability? }(0=\text { weak; } 1=\text { strong })\end{array}$ & Fry et al. (BoE) \\
\hline Target Independence & $\begin{array}{l}\text { Dummy }=1 \text { if CB has target } \\
\text { independence }\end{array}$ & $\begin{array}{l}\text { Lybek and } \\
\text { Morris }\end{array}$ \\
\hline Target Independence Score & Independence score $(0=$ low; $1=$ high $)$ & Fry et al. (BoE) \\
\hline Instrument Independence & $\begin{array}{l}\text { Dummy }=1 \text { if CB has instrument } \\
\text { independence }\end{array}$ & $\begin{array}{l}\text { Lybek and } \\
\text { Morris }\end{array}$ \\
\hline Instrument Independence Score & Independence score $(0=$ low; $1=$ high $)$ & Fry et al. (BoE) \\
\hline Limited or No Autonomy & Dummy $=1$ if CB has goal independence & $\begin{array}{l}\text { Lybek and } \\
\text { Morris }\end{array}$ \\
\hline $\begin{array}{l}\text { Limited Central Bank Financing } \\
\text { of Government Deficit }\end{array}$ & Independence score $(0=$ low; $1=$ high $)$ & Fry et al. (BoE) \\
\hline $\begin{array}{l}\text { Authority over Exchange Rate } \\
\text { Policy }\end{array}$ & $\begin{array}{l}\text { Dummy }=1 \text { if CB has authority over } \\
\text { exchange rate policy }\end{array}$ & $\begin{array}{l}\text { Lybek and } \\
\text { Morris }\end{array}$ \\
\hline $\begin{array}{l}\text { Goal Independence or Exchange } \\
\text { Rate Policy Authority }\end{array}$ & $\begin{array}{l}\text { Dummy }=1 \text { if } \mathrm{CB} \text { has either goal } \\
\text { independence or authority over exchange } \\
\text { rate policy }\end{array}$ & $\begin{array}{l}\text { Lybek and } \\
\text { Morris }\end{array}$ \\
\hline Fixed Exchange Rate, RR & Dummy $=1$ if fixed exchange rate regime & $\begin{array}{l}\text { Reinhart and } \\
\text { Rogoff }\end{array}$ \\
\hline Floating Exchange Rate, RR & $\begin{array}{l}\text { Dummy }=1 \text { if floating exchange rate } \\
\text { regime }\end{array}$ & $\begin{array}{l}\text { Reinhart and } \\
\text { Rogoff }\end{array}$ \\
\hline Fixed Exchange Rate, LYS & Dummy $=1$ if fixed exchange rate regime & $\begin{array}{l}\text { Levy-Y.\& } \\
\text { Sturzenegger }\end{array}$ \\
\hline Floating Exchange Rate, LYS & $\begin{array}{l}\text { Dummy }=1 \text { if floating exchange rate } \\
\text { regime }\end{array}$ & $\begin{array}{l}\text { Levy-Y.\& } \\
\text { Sturzenegger }\end{array}$ \\
\hline Fixed Exchange Rate, IMF & Dummy $=1$ if fixed exchange rate regime & IMF \\
\hline Floating Exchange Rate, IMF & $\begin{array}{l}\text { Dummy }=1 \text { if floating exchange rate } \\
\text { regime }\end{array}$ & IMF \\
\hline Term Length & Term length of board members (de jure) & $\begin{array}{l}\text { Lybek and } \\
\text { Morris }\end{array}$ \\
\hline Term Length in CB Law & $\begin{array}{l}\text { Dummy }=1 \text { if term length stipulated in } \\
\text { central bank law }\end{array}$ & $\begin{array}{l}\text { Lybek and } \\
\text { Morris }\end{array}$ \\
\hline Staff & Staff number & $\begin{array}{l}\text { Central Bank } \\
\text { Directory }\end{array}$ \\
\hline Staff \% Population & Staff/Population & $\begin{array}{l}\text { Central Bank } \\
\text { Directory \& Rose }\end{array}$ \\
\hline Operating Expenditures & Operating expenditures & Ize \\
\hline Establishment Year & Establishment year & $\begin{array}{l}\text { Central Bank } \\
\text { Directory }\end{array}$ \\
\hline
\end{tabular}




\section{DESCRIPTIVE StatisticS}

\begin{tabular}{|c|c|c|c|c|c|}
\hline Variable & Obs. & Mean & Std. Dev. & Min. & Max. \\
\hline MPC & 84 & 2.85 & 0.87 & 1 & 5 \\
\hline Population & 98 & 37.44 & 132.02 & 0.27 & 1262.65 \\
\hline Area & 98 & 0.997 & 2.588 & 0.0004 & 17.075 \\
\hline Real GDP (USD) & 95 & 0.313 & 1.194 & 0.0004 & 10.300 \\
\hline Real GDP (PPP) & 93 & 0.430 & 1.308 & 0.002 & 10.300 \\
\hline Ethnolinguistic Fractionalization & 62 & 0.38 & 0.29 & 0.00 & 0.93 \\
\hline Ethnic Fractionalization, $\mathrm{CH}$ & 77 & 36.92 & 27.70 & 0.00 & 93.00 \\
\hline Ethnic Fractionalization, ADEKW & 47 & 0.42 & 0.25 & 0.01 & 0.86 \\
\hline Linguistic Diversity & 98 & 0.43 & 0.29 & 0.003 & 0.99 \\
\hline Linguistic Fractionalization & 94 & 0.37 & 0.27 & 0.002 & 0.90 \\
\hline Religious Fractionalization & 97 & 0.46 & 0.23 & 0.002 & 0.86 \\
\hline Gini Coefficient & 74 & 40.00 & 10.83 & 24.40 & 70.00 \\
\hline Geographic Dispersion & 72 & 0.63 & 0.18 & 0.19 & 0.97 \\
\hline Administrative Divisions & 97 & 22.65 & 29.35 & 0 & 195 \\
\hline Real GDP per capita (USD) & 94 & 10.02 & 9.53 & 0.46 & 35.13 \\
\hline Real GDP per capita (PPP) & 97 & 7.48 & 10.09 & 0.13 & 39.32 \\
\hline Human Development Index & 74 & 0.74 & 0.17 & .34 & 0.95 \\
\hline Urbanization & 98 & 59.10 & 22.60 & 6.15 & 100.00 \\
\hline M3 & 85 & 48.80 & 38.26 & 8.17 & 193.41 \\
\hline Domestic Bank Credit & 94 & 65.14 & 57.20 & 3.83 & 317.22 \\
\hline Trade Openness & 91 & 83.14 & 38.08 & 20.18 & 228.88 \\
\hline Landlocked & 98 & 0.21 & 0.41 & 0 & 1 \\
\hline Business Cycle Correlation & 97 & 0.18 & 0.31 & -0.49 & 0.80 \\
\hline Democracy & 90 & 6.03 & 3.78 & 0 & 10 \\
\hline Autocracy & 90 & 1.68 & 2.83 & 0 & 10 \\
\hline Polity & 90 & 4.36 & 6.36 & -10 & 10 \\
\hline Political Rights & 98 & 3.18 & 2.09 & 1 & 7 \\
\hline Civil Rights & 98 & 3.36 & 1.69 & 1 & 7 \\
\hline Economic Freedom & 76 & 6.65 & 0.96 & 4.66 & 8.56 \\
\hline Economic Security & 58 & 0.52 & 0.23 & 0.05 & 0.98 \\
\hline Voice \& Accountability & 98 & 0.14 & 0.92 & -1.75 & 1.64 \\
\hline Political Stability & 96 & 0.17 & 0.98 & -2.38 & 1.73 \\
\hline Government Effectiveness & 97 & 0.23 & 1.04 & -1.58 & 2.48 \\
\hline Regulatory Quality & 98 & 0.25 & 0.91 & -2.14 & 2.27 \\
\hline Rule of Law & 98 & 0.25 & 1.07 & -1.52 & 2.22 \\
\hline Deficit & 82 & -2.90 & 3.34 & -13.65 & 10.85 \\
\hline Debt & 76 & 49.23 & 35.76 & 0 & 189.53 \\
\hline Central Bank Independence & 98 & 2.67 & 0.83 & 1 & 4 \\
\hline CB Independence Score & 93 & 73.5 & 16.2 & 24 & 98 \\
\hline Goal Independence & 98 & 0.16 & 0.37 & 0 & 1 \\
\hline Price Stability Focus & 93 & 0.76 & 0.20 & 0 & 1 \\
\hline Target Independence & 98 & 0.42 & 0.50 & 0 & 1 \\
\hline Target Independence Score & 93 & 0.58 & 0.31 & 0 & 1 \\
\hline Instrument Independence & 98 & 0.35 & 0.48 & 0 & 1 \\
\hline Instrument Independence Score & 93 & 0.82 & 0.29 & 0 & 1 \\
\hline
\end{tabular}




\begin{tabular}{|l|l|l|l|l|l|}
\hline Limited or No Autonomy & 98 & 0.07 & 0.26 & 0 & 1 \\
\hline $\begin{array}{l}\text { Limited Central Bank Financing of } \\
\text { Government Deficit }\end{array}$ & 93 & 0.76 & 0.27 & 0 & 1 \\
\hline Authority over Exchange Rate Policy & 98 & 0.09 & 0.29 & 0 & 1 \\
\hline Goal Indep. or Exch. Rate Policy Auth. & 98 & 0.33 & 0.47 & 0 & 1 \\
\hline Fixed Exchange Rate, RR & 98 & 0.22 & 0.42 & 0 & 1 \\
\hline Floating Exchange Rate, RR & 98 & 0.06 & 0.24 & 0 & 1 \\
\hline Fixed Exchange Rate, LYS & 98 & 0.45 & 0.50 & 0 & 1 \\
\hline Floating Exchange Rate, LYS & 98 & 0.30 & 0.46 & 0 & 1 \\
\hline Fixed Exchange Rate, IMF & 98 & 0.37 & 0.48 & 0 & 1 \\
\hline Floating Exchange Rate, IMF & 98 & 0.53 & 0.50 & 0 & 1 \\
\hline Term Length & 70 & 5.19 & 1.97 & 3 & 14 \\
\hline Term Length in CB Law & 98 & 0.84 & 0.37 & 0 & 1 \\
\hline Staff & 89 & 4.04 & 18.03 & 0.10 & 150.00 \\
\hline Staff \% Population & 89 & 0.01 & 0.01 & 0.002 & 0.09 \\
\hline Operating Expenditures & 99 & 0.243 & 0.567 & 0.004 & 3.626 \\
\hline Establishment Year & 98 & 1939 & 59.33 & 1668 & 1997 \\
\hline
\end{tabular}


IV. SCATter Plots

Panel A1: Size

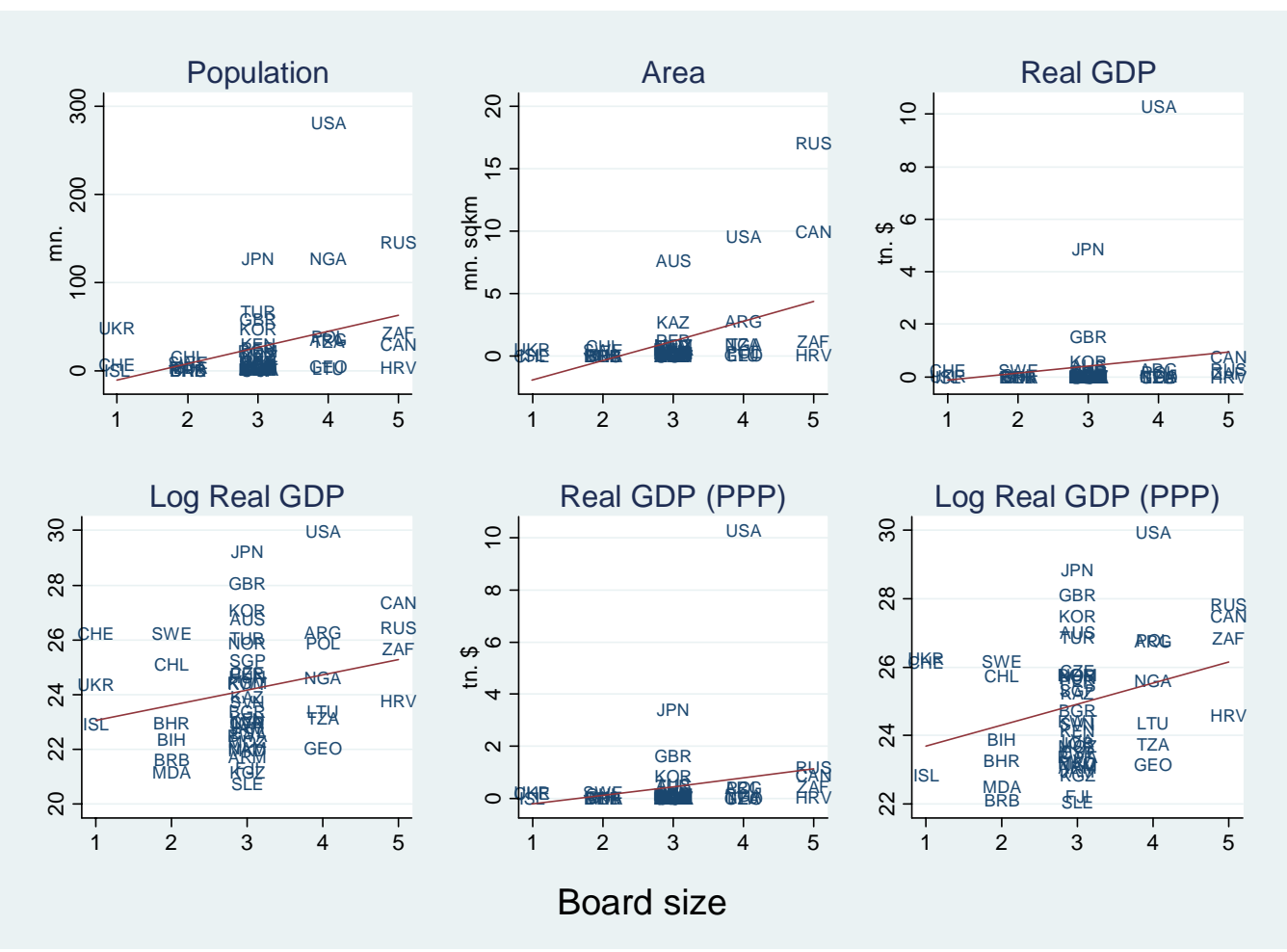

\section{Panel A2: Heterogeneity}
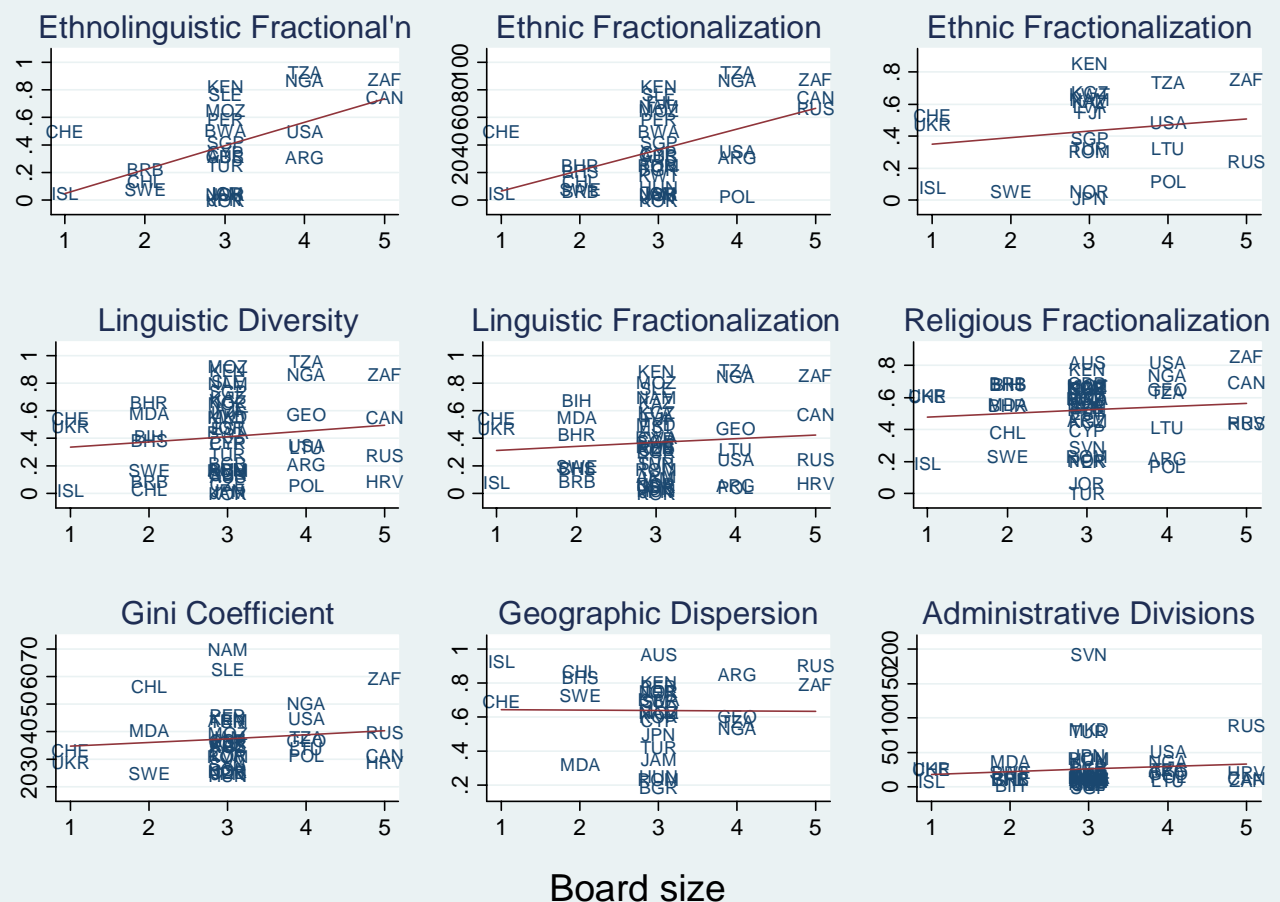

Board size 


\section{Panel B: Level of Development and Openness}
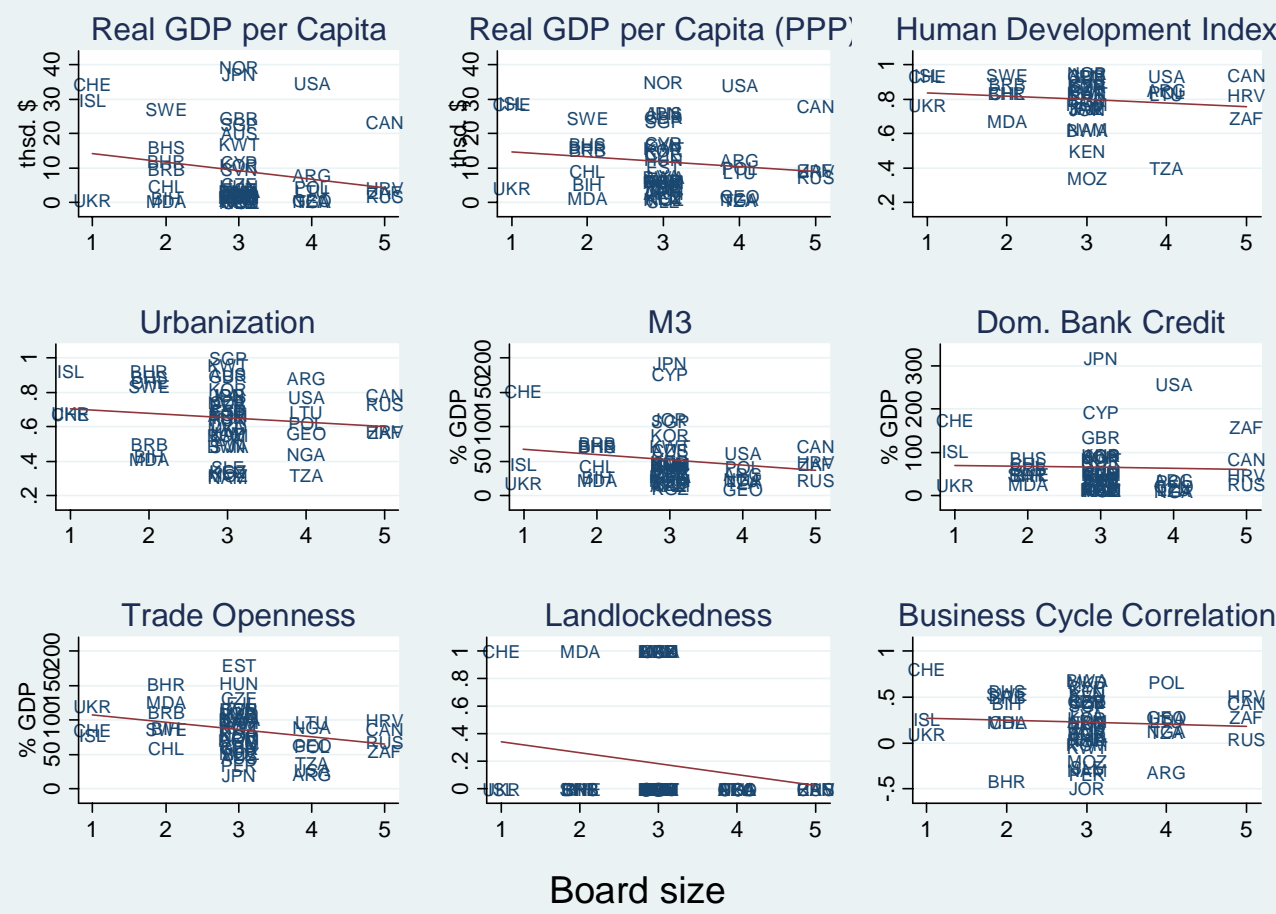

Panel C: Political Regime
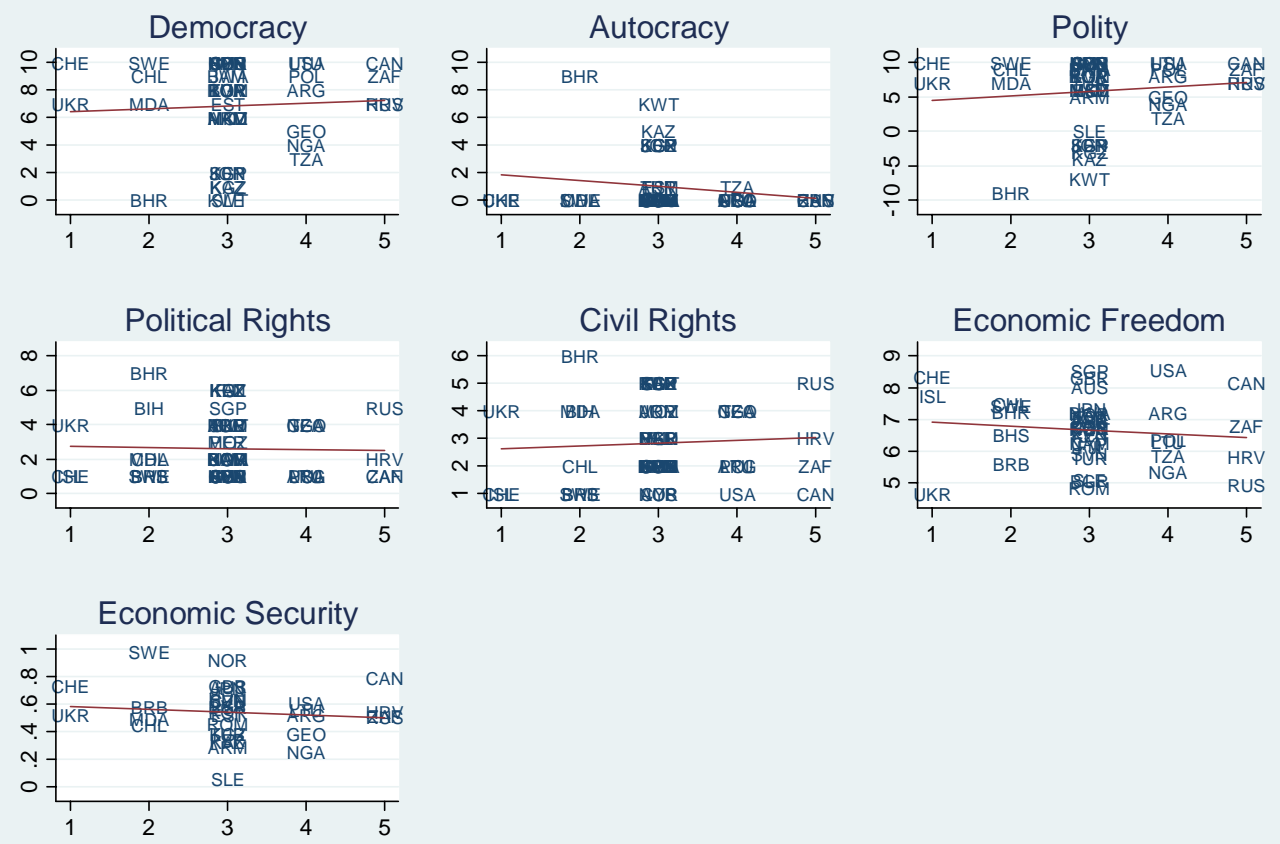

Board size 


\section{Panel C (concluded): Political Regime}
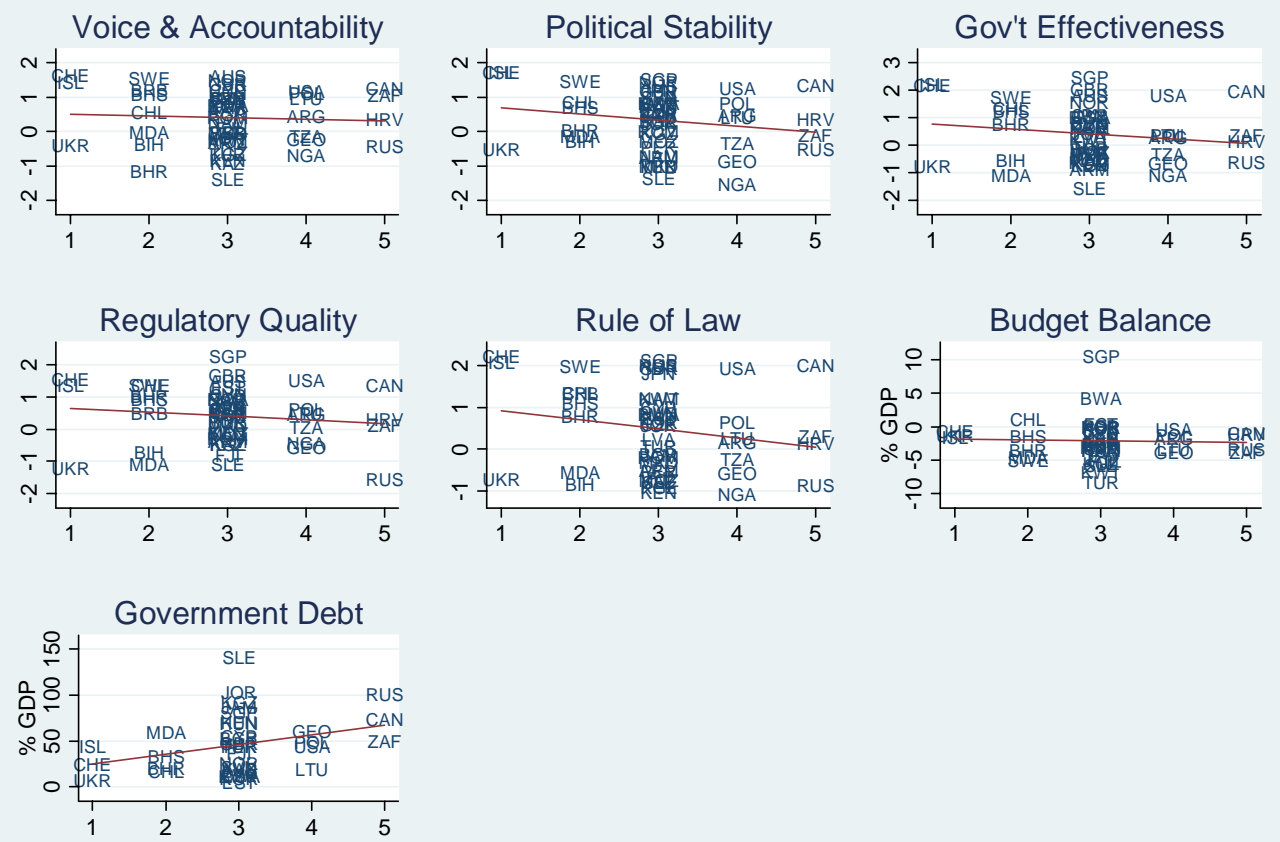

\section{Board size}

\section{Panel D: Central Bank Characteristics}
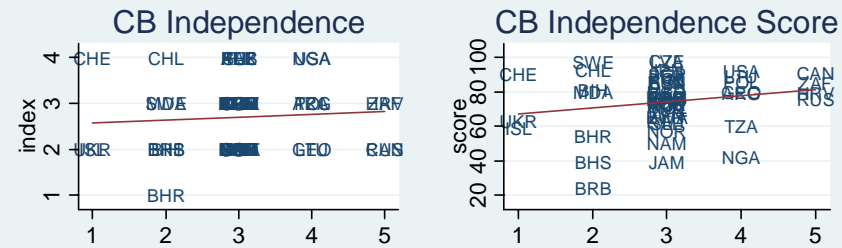

Price Stability Focus

Target Independence Scorє
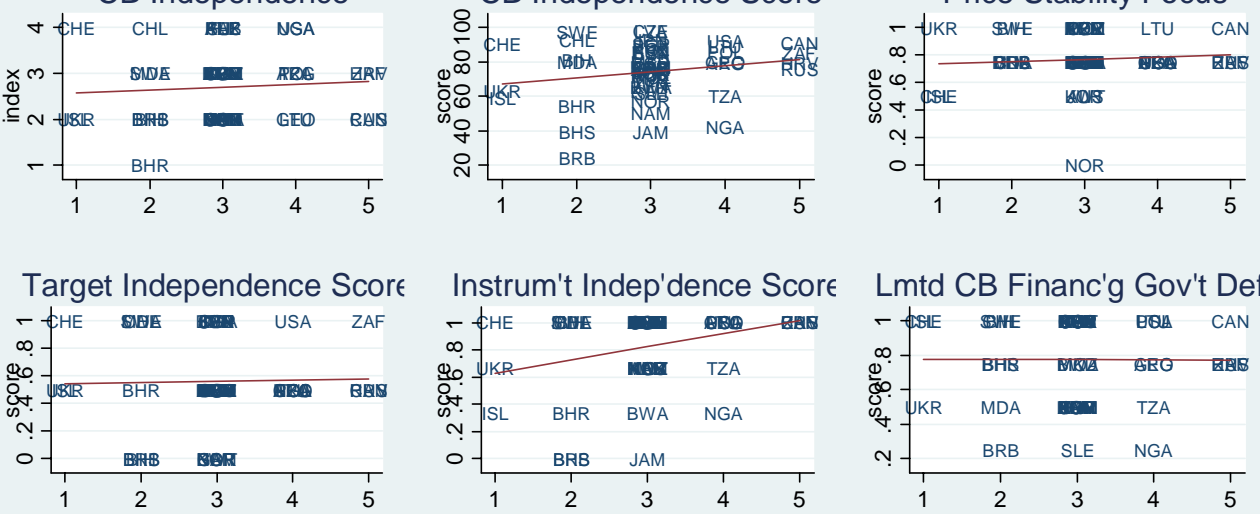

Lmtd CB Financ'g Gov't Def't
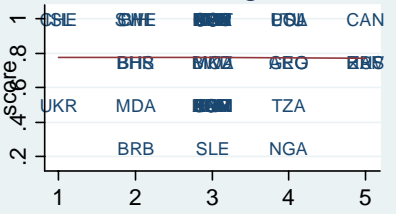

FX Regime, RR

FX Regime, LSY

FX Regime, IMF
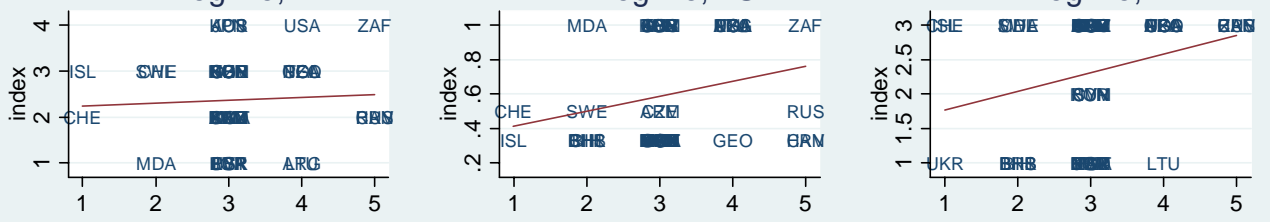

Board size 
Panel D (concluded): Central Bank Characteristics
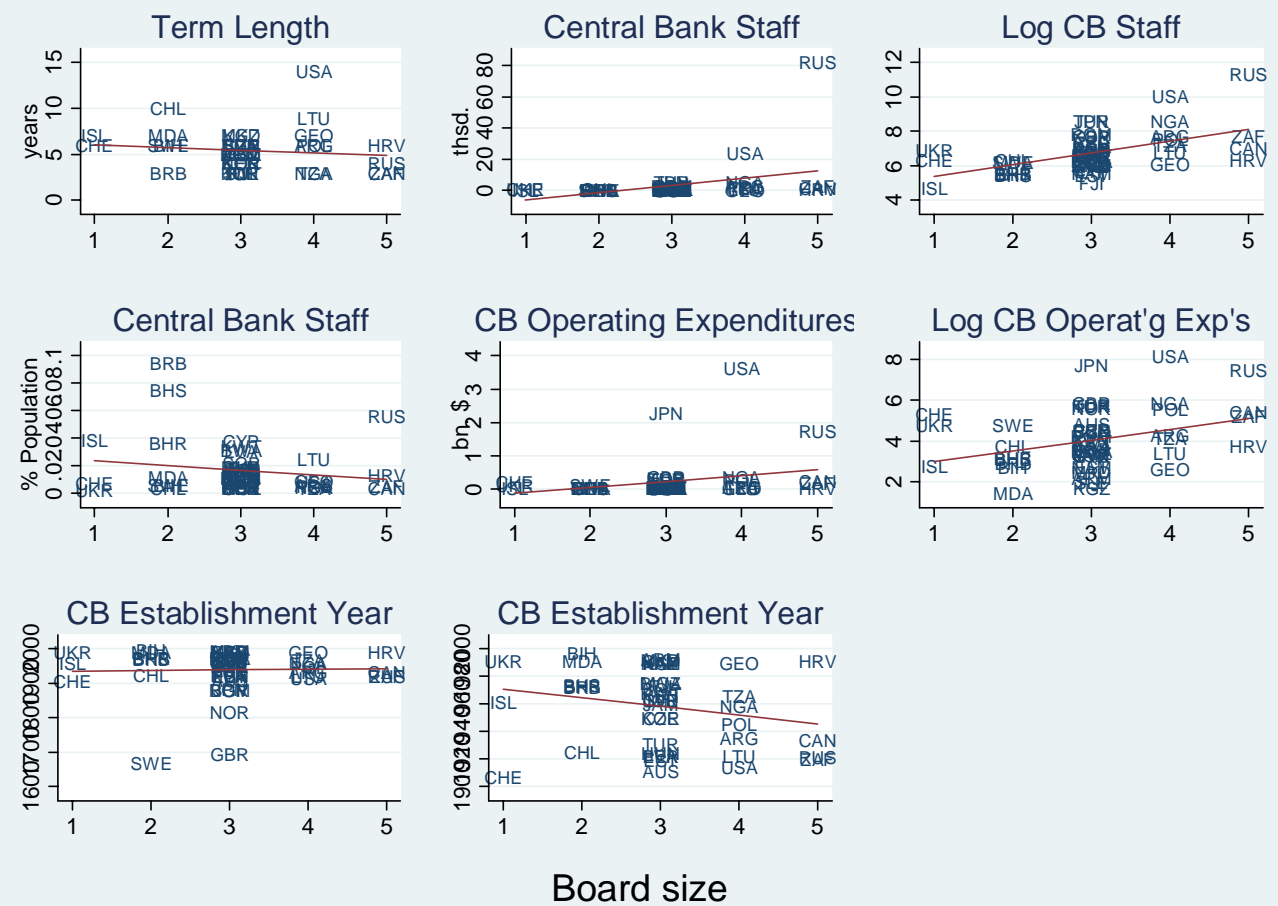
V. BOARD SIZE AND TERM LENGTH

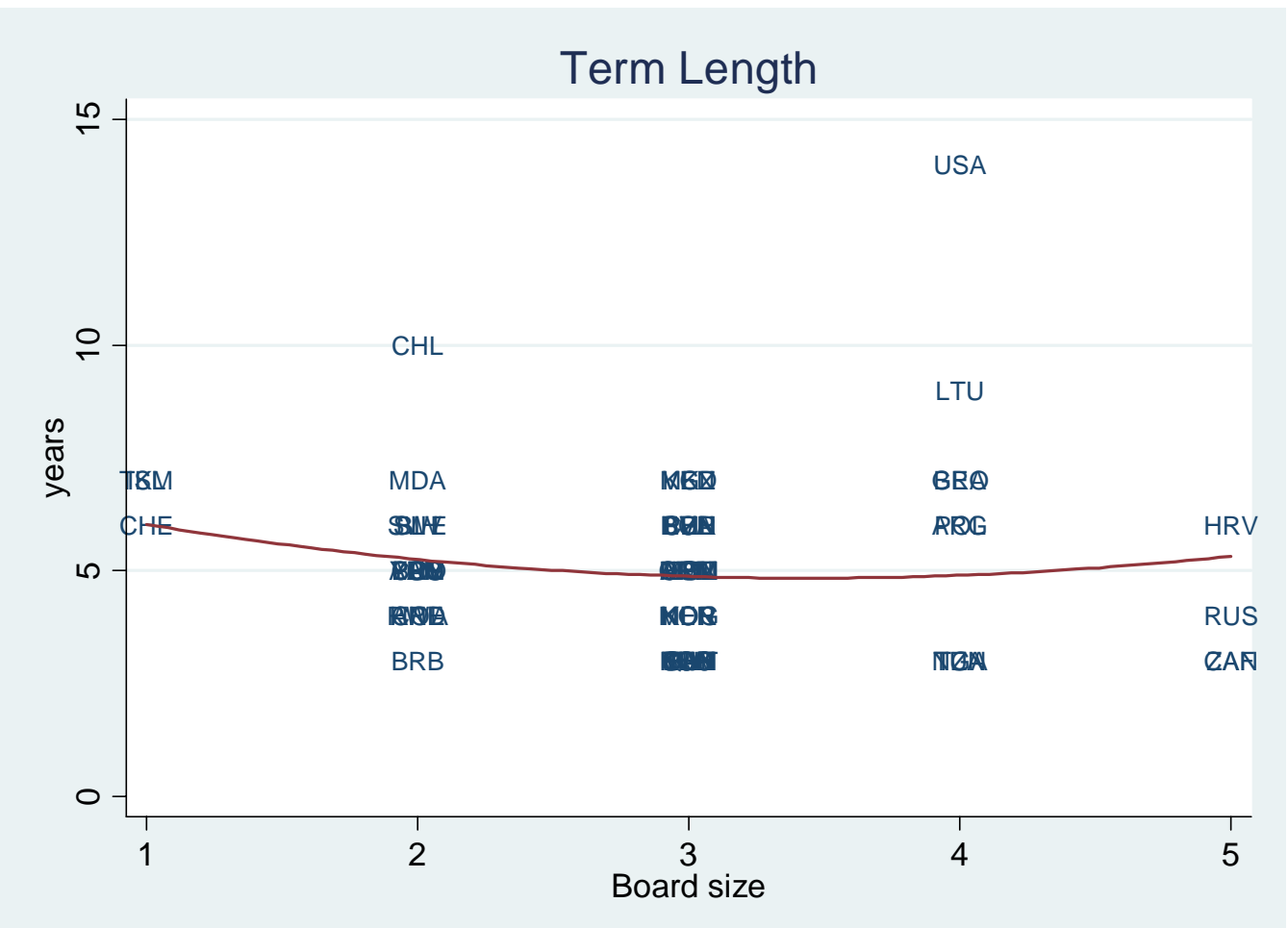




\section{CESifo Working Paper Series}

(for full list see www.cesifo-group.de)

1836 Peter Backé and Cezary Wójcik, Catching-up and Credit Booms in Central and Eastern European EU Member States and Acceding Countries: An Interpretation within the New Neoclassical Synthesis Framework, October 2006

1837 Lars P. Feld, Justina A.V. Fischer and Gebhard Kirchgaessner, The Effect of Direct Democracy on Income Redistribution: Evidence for Switzerland, October 2006

1838 Michael Rauscher, Voluntary Emission Reductions, Social Rewards, and Environmental Policy, November 2006

1839 Vincent Vicard, Trade, Conflicts, and Political Integration: the Regional Interplays, November 2006

1840 Erkki Koskela and Mikko Puhakka, Stability and Dynamics in an Overlapping Generations Economy under Flexible Wage Negotiation and Capital Accumulation, November 2006

1841 Thiess Buettner, Michael Overesch, Ulrich Schreiber and Georg Wamser, Taxation and Capital Structure Choice - Evidence from a Panel of German Multinationals, November 2006

1842 Guglielmo Maria Caporale and Alexandros Kontonikas, The Euro and Inflation Uncertainty in the European Monetary Union, November 2006

1843 Jan K. Brueckner and Ann G. Largey, Social Interaction and Urban Sprawl, November 2006

1844 Eytan Sheshinski, Differentiated Annuities in a Pooling Equilibrium, November 2006

1845 Marc Suhrcke and Dieter Urban, Are Cardiovascular Diseases Bad for Economic Growth?, November 2006

1846 Sam Bucovetsky and Andreas Haufler, Preferential Tax Regimes with Asymmetric Countries, November 2006

1847 Luca Anderlini, Leonardo Felli and Andrew Postlewaite, Should Courts always Enforce what Contracting Parties Write?, November 2006

1848 Katharina Sailer, Searching the eBay Marketplace, November 2006

1849 Paul De Grauwe and Pablo Rovira Kaltwasser, A Behavioral Finance Model of the Exchange Rate with Many Forecasting Rules, November 2006

1850 Doina Maria Radulescu and Michael Stimmelmayr, ACE vs. CBIT: Which is Better for Investment and Welfare?, November 2006 
1851 Guglielmo Maria Caporale and Mario Cerrato, Black Market and Official Exchange Rates: Long-Run Equilibrium and Short-Run Dynamics, November 2006

1852 Luca Anderlini, Leonardo Felli and Andrew Postlewaite, Active Courts and Menu Contracts, November 2006

1853 Andreas Haufler, Alexander Klemm and Guttorm Schjelderup, Economic Integration and Redistributive Taxation: A Simple Model with Ambiguous Results, November 2006

1854 S. Brock Blomberg, Thomas DeLeire and Gregory D. Hess, The (After) Life-Cycle Theory of Religious Contributions, November 2006

1855 Albert Solé-Ollé and Pilar Sorribas-Navarro, The Effects of Partisan Alignment on the Allocation of Intergovernmental Transfers. Differences-in-Differences Estimates for Spain, November 2006

1856 Biswa N. Bhattacharyay, Understanding the Latest Wave and Future Shape of Regional Trade and Cooperation Agreements in Asia, November 2006

1857 Matz Dahlberg, Eva Mörk, Jørn Rattsø and Hanna Ågren, Using a Discontinuous Grant to Identify the Effect of Grants on Local Taxes and Spending, November 2006

1858 Ernesto Crivelli and Klaas Staal, Size and Soft Budget Constraints, November 2006

1859 Jens Brøchner, Jesper Jensen, Patrik Svensson and Peter Birch Sørensen, The Dilemmas of Tax Coordination in the Enlarged European Union, November 2006

1860 Marcel Gérard, Reforming the Taxation of Multijurisdictional Enterprises in Europe, "Coopetition" in a Bottom-up Federation, November 2006

1861 Frank Blasch and Alfons J. Weichenrieder, When Taxation Changes the Course of the Year - Fiscal Year Adjustments and the German Tax Reform 2000/2001, November 2006

1862 Hans Jarle Kind, Tore Nilssen and Lars Sørgard, Competition for Viewers and Advertisers in a TV Oligopoly, November 2006

1863 Bart Cockx, Stéphane Robin and Christian Goebel, Income Support Policies for PartTime Workers: A Stepping-Stone to Regular Jobs? An Application to Young LongTerm Unemployed Women in Belgium, December 2006

1864 Sascha O. Becker and Marc-Andreas Muendler, The Effect of FDI on Job Separation, December 2006

1865 Christos Kotsogiannis and Robert Schwager, Fiscal Equalization and Yardstick Competition, December 2006

1866 Mikael Carlsson, Stefan Eriksson and Nils Gottfries, Testing Theories of Job Creation: Does Supply Create Its Own Demand?, December 2006 
1867 Jacques H. Drèze, Charles Figuières and Jean Hindriks, Voluntary Matching Grants Can Forestall Social Dumping, December 2006

1868 Thomas Eichner and Marco Runkel, Corporate Income Taxation of Multinationals and Unemployment, December 2006

1869 Balázs Égert, Central Bank Interventions, Communication and Interest Rate Policy in Emerging European Economies, December 2006

1870 John Geweke, Joel Horowitz and M. Hashem Pesaran, Econometrics: A Bird's Eye View, December 2006

1871 Hans Jarle Kind, Marko Koethenbuerger and Guttorm Schjelderup, Taxation in TwoSided Markets, December 2006

1872 Hans Gersbach and Bernhard Pachl, Cake Division by Majority Decision, December 2006

1873 Gunther Schnabl, The Evolution of the East Asian Currency Baskets - Still Undisclosed and Changing, December 2006

1874 Horst Raff and Michael J. Ryan, Firm-Specific Characteristics and the Timing of Foreign Direct Investment Projects, December 2006

1875 Jukka Pirttilä and Håkan Selin, How Successful is the Dual Income Tax? Evidence from the Finnish Tax Reform of 1993, December 2006

1876 Agnieszka Stążka, Sources of Real Exchange Rate Fluctuations in Central and Eastern Europe - Temporary or Permanent?, December 2006

1877 Xavier Calsamiglia, Teresa Garcia-Milà and Therese J. McGuire, Why do Differences in the Degree of Fiscal Decentralization Endure?, December 2006

1878 Natacha Gilson, How to be Well Shod to Absorb Shocks? Shock Synchronization and Joining the Euro Zone, December 2006

1879 Scott Alan Carson, Modern Health Standards for Peoples of the Past: Biological Conditions by Race in the American South, 1873 - 1919, December 2006

1880 Peter Huber, Michael Pfaffermayr and Yvonne Wolfmayr, Are there Border Effects in the EU Wage Function?, December 2006

1881 Harry Flam and Håkan Nordström, Euro Effects on the Intensive and Extensive Margins of Trade, December 2006

1882 Panu Poutvaara and Mikael Priks, Hooliganism in the Shadow of the 9/11 Terrorist Attack and the Tsunami: Do Police Reduce Group Violence?, December 2006

1883 Ruud A. de Mooij and Gaëtan Nicodème, Corporate Tax Policy, Entrepreneurship and Incorporation in the EU, December 2006 
1884 Johannes Becker and Clemens Fuest, Corporate Tax Policy and International Mergers and Acquisitions - Is the Tax Exemption System Superior?, January 2007

1885 Momi Dahan and Udi Nisan, The Effect of Benefits Level on Take-up Rates: Evidence from a Natural Experiment, January 2007

1886 José García-Solanes, Francisco I. Sancho-Portero and Fernando Torrejón-Flores, Beyond the Salassa-Samuelson Effect in some New Member States of the European Union, January 2007

1887 Peter Egger, Wolfgang Eggert and Hannes Winner, Saving Taxes Through Foreign Plant Ownership, January 2007

1888 Timothy J. Goodspeed and Andrew Haughwout, On the Optimal Design of Disaster Insurance in a Federation, January 2007

1889 Wim Groot, Henriëtte Maassen van den Brink and Bernard van Praag, The Compensating Income Variation of Social Capital, January 2007

1890 Bas Jacobs, Ruud A. de Mooij and Kees Folmer, Analyzing a Flat Income Tax in the Netherlands, January 2007

1891 Hans Jarle Kind, Guttorm Schjelderup and Frank Stähler, Newspapers and Advertising: The Effects of Ad-Valorem Taxation under Duopoly, January 2007

1892 Erkki Koskela and Rune Stenbacka, Equilibrium Unemployment with Outsourcing under Labour Market Imperfections, January 2007

1893 Maarten Bosker, Steven Brakman, Harry Garretsen, Herman de Jong and Marc Schramm, The Development of Cities in Italy 1300 - 1861, January 2007

1894 Michel Beine, Oscar Bernal, Jean-Yves Gnabo and Christelle Lecourt, Intervention Policy of the BoJ: A Unified Approach, January 2007

1895 Robert S. Chirinko and Daniel J. Wilson, State Investment Tax Incentives: A Zero-Sum Game?, January 2007

1896 Theo S. Eicher and Oliver Roehn, Sources of the German Productivity Demise Tracing the Effects of Industry-Level ICT Investment, January 2007

1897 Helge Berger, Volker Nitsch and Tonny Lybek, Central Bank Boards around the World: Why does Membership Size Differ?, January 2007 